\title{
A review of the New World Chlidanotini (Lepidoptera, Tortricidae)
}

\author{
Józef Razowski ${ }^{1}$ \\ Vitor Osmar Becker ${ }^{2}$
}

\begin{abstract}
The New World taxa of the pantropical Chlidanotinae tribe Chlidanotini (Lepidoptera, Tortricidae) are reviewed. Twenty seven species and two subspecies are described as new: Auratonota auriginea, A. badiaurea, A. clasmata, A. exoptata and A. tessellata (Brazil); A. paidosocia and A. spinivalva cubana (Cuba); A. cataponera, A. flora, A. foederata, A. monochroma, A. moronana, A. nugax, A. petalocrossa maldonada, A. splendida, A. stigmosa and A. virgata (Ecuador); A. effera, A. oxytenia, A. serotina and A. spinivalva spinivalva (Mexico); A. magnifica (Venezuela); Heppnerographa brasiliana and $H$. lapilla (Brazil); H. ardea, H. carchiana and H. ecuatorica (Ecuador). Three new combinations are also established: Auratonota hyacinthina (Meyrick, 1911), A. multifurcata (Meyrick, 1932), and Heppnerographa tricesimana (Zeller, 1877).
\end{abstract}

KEY WORDS. Tortricidae, Chlidanotini, Neotropical, systematics, distribution

The Chlidanotini, with the Polyorthini and Hilarographini, form the tortricid subfamily Chlidanotinae. This subfamily is defined by several synapomorphies (TUCK 1981; HORAK \& BROWN 1991). The phylogenetic relationships between the tribes are provided by POINAR \& BROWN (1993). The apomorphies of Chlidanotini are the flattened antenna without conspicuous setae, and the apical portion of forewing bent upwards at rest. This tribe is closely related to Hilarographini sharing two synapomorphies: the presence of hami, and the brush-shaped signum extending from vicinity of the accessory bursa (RAZOWSKI 1987; POINAR \& BROWN 1993).

The apomorphies of the Hilarographini described by POINAR \& BROWN (1993) are the smooth scaled, upturned labial palpi, the presence of large ocelli, the bisetose prespiracular pinacula in larval prothorax, the coloration, and probably also the presence of a notch below the forewing apex. The musculature of male genitalia of Chlidanotini and Hilarographini were described by RAZOWSKI (1981). The Neotropical Chlidanotini, apart from the apomorphies mentioned above, are characterized by lacking chorda and the M-stem on fore wings, and the absense of appressed scales on fore wings. According to POINAR \& BROWN (1993) the ocelli are small, however this character is variable. The members of this tribe are also

1) Institute of Systematics and Evolution of Animals, Polish Academy of Sciences. Slawkowska 17, 31-016 Kraków, Poland.

2) Departamento de Zoologia, Universidade de Brasília. Caixa Postal 04525, 70919-970 Brasília, Distrito Federal, Brasil. Research Associate. 
easily distinguished from Hilarographini and Chlidanotini of other regions by the fasciate markings (RAzowSKI 1987). Other characters are as folows: in male genitalia the socii are variably developed but always present, being weakly sclerotized in some species, whereas rather rigid in others. The trend of sclerotization of the socii and fusion of hami and socii is not correlated with other characters. The sclerotization of socii is observed also in Hilarographini and this character was used for separation of two genera in this tribe. In several species of Auratonota (e.g. A. aenigmatica (Meyrick, 1912) and its allies) and in Macrochlidia Brown, 1990, the socii are rigid, thin, tapering terminally, while in Monortha Razowski \& Becker, 1981, they are broad. The hami in primitive taxa are long, well sclerotized, while in some are more specialized, reduced, fused with hami, or absent. In Auratonota Razowski, 1987, and Utrivalva Razowski, 1987, the basal parts of the socii and hami are fused to various degrees. In Heppnerographa Razowski, 1987, this fusion is complete and the sclerotization of the hami is usually strong. In all known species the gnathos is strongly reduced, without terminal plate, and its arms are linked by means of a broad membrane or weak sclerite. The aedeagus is characteristic of the subfamily, in major part weakly sclerotized. The outer slit of valvae are variable, often absent.

Their immatures and biology are unknown. Food-plant of only one species (Auratonota dispersa Brown, 1990), feeding on an orchid species, has been recorded (BROWN 1990a).

Range. The tribe is tropical and subtropical in distribution. BROWN (1990a) found Auratonota dispersa in Florida but he mentioned that there is no evidence of its establishment there. In this paper several species from Mexico, with the most northern records in Tamaulipas are presented. The tribe ranges from Mexico to Cuba and Dominica as far south as Santa Catarina, southern Brazil.

The phylogeny of Neotropical Chlidanotini is still provisional. The six genera may be arranged as follows. Auratonota does not show any autapomorphy and the plesiomorphies are variable. These are the usually distinct separation of the hami and socii, the simple valvae, the naked ventral portion of uncus, etc. Pseudocomotis Brown, 1989 and Macrochlidia are very close to Auratonota. The presumed autapomorphies of Pseudocomotis are the free distal end of the sacculus and, the presence of a patch of spines near the mid-venter of valvae. Macrochlidia is defined by the rigid hami fused with socii. The large medial flap from transtilla described by BROWN (1990b) as a putative autapomorphy is, however, known in some other Chlidanotini, e.g. in Auratonota badiaura. Utrivalva has the base of hami always fused with socii, a presumed convergence (shared with Auratonota and Macrochlidia), and is defined by two supposed autapomorphies: the strongly expanded ventro-terminal part of uncus and the dorso-basal lobe of valvae. In Heppnerographa the socii are completely fused with the hami to form an often rigid process (exceptionally membranous in a few species). Monorta has two presumed autapomorphies: the very small hami developed as a submedian expansion of the tegumen and the heavily spined socii. 
The holotypes of the new species described here are deposited in the collection of V. O. Becker, Brasília (VOB), except for those indicated otherwise. The numbers in square brackets "[]" are the entry number of the specimens in the register books of VOB. Representatives of several species originally from VOB have been donated to the Institute of Systematics and Evolution of Animals, Kraków, Poland (ISEZ). Other abbreviations used in text are: AMNH (American Museum of Natural History, New York); BMNH (The Natural History Museum, London); G. S. (Genitalia slide); MNHU (Museum für Naturkunde der HumboldtUniversität, Berlin); NHMV (Naturhistorisches Museum, Vienna); USNM (The National Museum of Natural History, Smithsonian Institution, Washington). All drawings are by the first author; photographs by Marek Kopec, Kraków and Sebastião Caldas (PROLAB), Brasília.

The number given in the descriptions for the labial palpi indicates the proportion of their total length to the diameter of eyes.

\section{SYSTEMATICS}

\section{Auratonota Razowski, 1987}

Auratonota Razowski, 1987: 62. Type-species: Cnephasia hydrogramma Meyrick, 1912: 683, by original designation.

This genus, originally described to contain four species, currently includes 32. No syanapomorphy has been found as all characters mentioned so far are considered as plesiomorphic or convergent. BROWN (1990a) mentioned three symplesiomorphies. Of these, the shape of valvae is convergent, and the absence of spine-like setae on the ventral surface of the uncus is most probably due to preparation (they were found now in all studied species and probably present species specific variation).

\section{Auratonota hydrogramma (Meyrick, 1912)}

Figs 9, 36-38, 109

Cnephasia hydrogramma Meyrick, 1912b: 683. Holotype male, Surinam: Paramaribo, VIII.1892 (BMNH) [examined].

Eulia hydrogramma; Clarke, 1958: 128, pl.64, figs 3-3b.

Auratonota hydrogramma; Razowski, 1987: 62.

Material examined. 14 specimens; 6, CosTA RicA: Turrialba, $600 \mathrm{~m}, 8 . \mathrm{VII}$, 5.VIII., 25.IX, 10.XI. (Becker) [3985, 4000, 4001, 4003, 4004, 34118] (VOB, ISEZ); PANAMA: Canal Zone, Barro Colorado Id., III, 19-20.VII (USNM); GUYANA: Potaro R., 2000 ft (AMNH); 1 male, BRAZIL: PA[rá], Belém, I.1984 (Becker) [47181] (VOB); 1 male, 1 female, AL[agoas]: Ibateguara, 10-20.III.1994 (Becker) [91069] (VOB); 1 male, 2 females, BA[hia]: Camacán, 21-30.IX.1991, 15.XI.1995 (Becker) [84401, 106342] (VOB).

Widespread throughout the lowlands neotropics, from Costa Rica to Bahia, in the Atlantic coast of Eastern Brazil, as seen from the material examined. The genitalia of the type are described by RAZOWSKI (1987). The genitalia of male (Figs 36-38) and female (Fig. 109) were based on material from Costa Rica: Turrialba. 

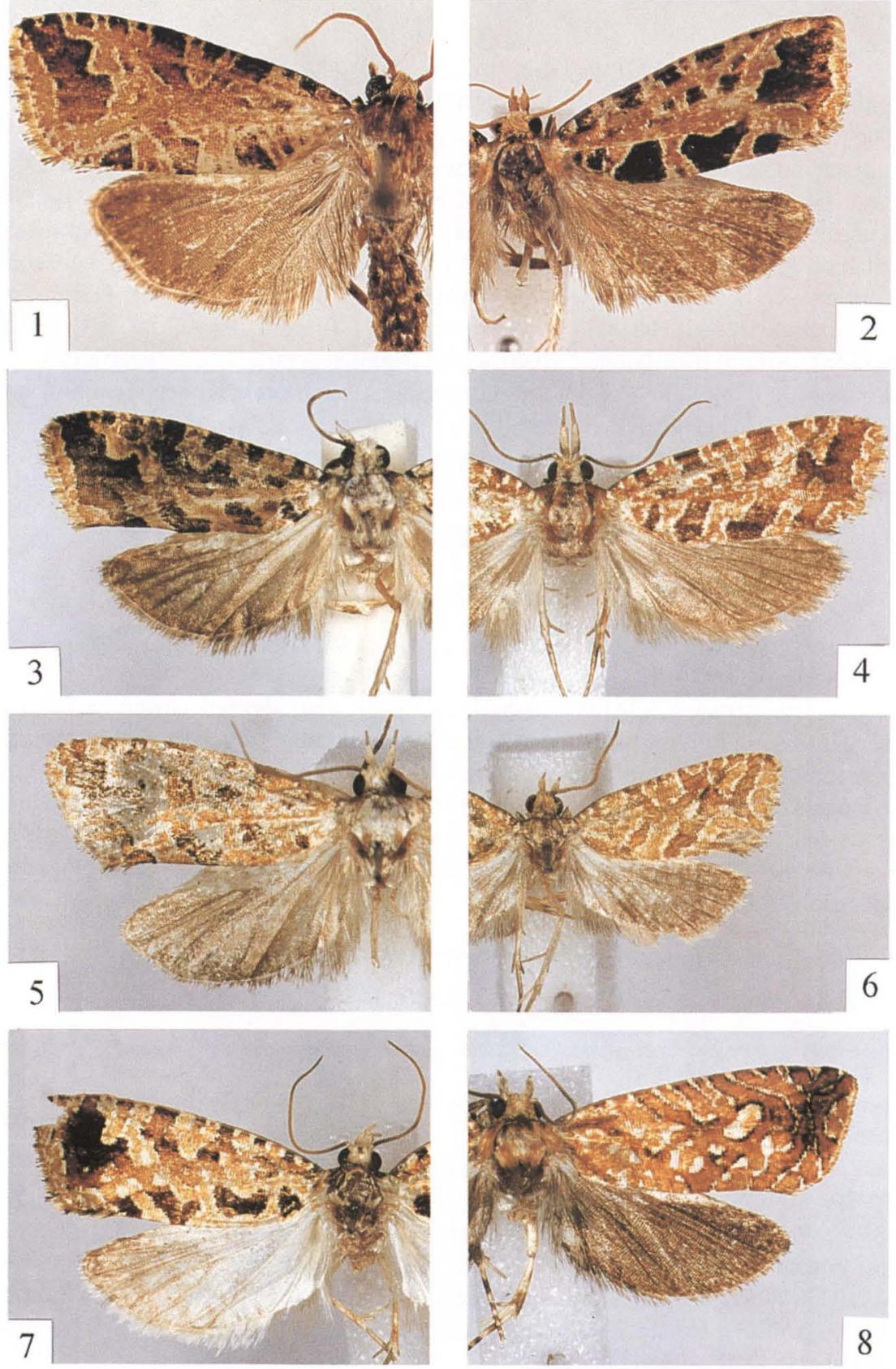

Figs 1-8. Adults of Auratonota. (1) A. petalocrossa petalocrossa, male, Costa Rica; (2) A. petalocrossa maldonada, male holotype, Ecuador; (3) A. spinivalva spinivalva, male holotype, Mexico; (4) A. spinivalva cubana, female paratype, Cuba; (5) A. serotina, male holotype, Mexico; (6) A. paidosocia, male holotype, Cuba; (7) A. stigmosa, male holotype, Ecuador; (8) A. flora, male holotype, Ecuador. 


\section{Auratonota petalocrossa petalocrossa (Meyrick, 1926)}

Figs $1,39,40,110,111$

Eulia petalocrossa Meyrick, 1926: 250. Lectotype male, Colombi^: Choco, El Tigre, Rio Tamaua, 320 ft, II.1909 (Palmer) (BMNH), designated by Clarke, 1958: 135 [examined]; Clarke, 1958: 135, pl. 67 , figs $3-3 \mathrm{~b}$.

Auratonota petalocrossa; Razowski, 1987: 62.

Material examined. 15 specimens; 6 males, 1 female, CosTA RicA: Turrialba, 600 m, 5, 20.VIII, 25.IX, 10.XI.1971, 10.X.1972, XI. 1973, 25.III.1973, VII.1981 (Becker) [3984, 3996- 3999, 4005, 4006, 4010, 4028, 4044, 34177, 46079]; 1, Volcan Turrialba, $1800 \mathrm{~m}, 13$. VIII (Becker) [4044]; 1 female, V.[illa] Neilly, 800 m, 26.XI.1973 (Becker) [3231]; 1, Limon, Guayacán, 28.VII.1972 (Becker) [3988] (VOB, ISEZ).

The specimens examined show some variation in having more or less pale and broad surfaces of ground colour, reduced parts of markings, or with broad markings and slender elements of ground colour suffused with brown.

Male genitalia (Figs 39, 40). Uncus strong, curved, broad basally, slender beyond it, slightly expanding apically; socii long, slender; hami slender, acute, somewhat longer than socii. Saccus long. Valvae rather slender, broadening postmedially; sacculus simple, broadest and convex postbasally; transtilla, a slender band. Aedeagus with delicate ventro-lateral lobe beyond middle.

Female genitalia (Figs 110, 111). Papillae anales broader than in A. hydrogramma, with very small anterior portion; sterigma short, weakly sclerotized distally, with fairly broad arms and distinctly convex proximal edge; anterior edge of ostium bursae delicately plicate; colliculum much slender than in former species; ductus bursae slender, tapering towards corpus bursae; ductus seminalis subdorsal, extending from small posterior portion of corpus bursae; sterigma short, weakly sclerotized distally, with fairly broad lateral part of the latter; accessory bursa as in A. hydrogramma; signum much smaller.

\section{Auratonota petalocrossa maldonada ssp.n.}

Figs 2, 41, 42

Wing span $26-28 \mathrm{~mm}$. Labial palpi 2 , yellowish cream, paler than in nominate subspecies. Ground-colour of forewing slightly darker and dorsal blotches much larger than in nominate form, glossy along edges of markings; markings dark brown; subterminal blotch very broad extending from apex to M3, with dorsal edge long, almost straight.

Male genitalia (Figs 41, 42) as in nominate form but with slightly longer socii and slenderer valvae.

Holotype male. ECUADOR: Carchi, Maldonado, 2200 m, 9-11.I.1993 (Becker) [105231], G.S. 21875. Paratype male: same data (VOB).

\section{Auratonota aporema (Dognin, 1912)}

Cnephasia aporema Dognin, 1912: 49. Holotype male, ColomBIA: San Jose (USNM) [examined]. Auratonota aporema; Brown, 1990a: 156.

Probably a synonym of $A$. hydrogramma. 

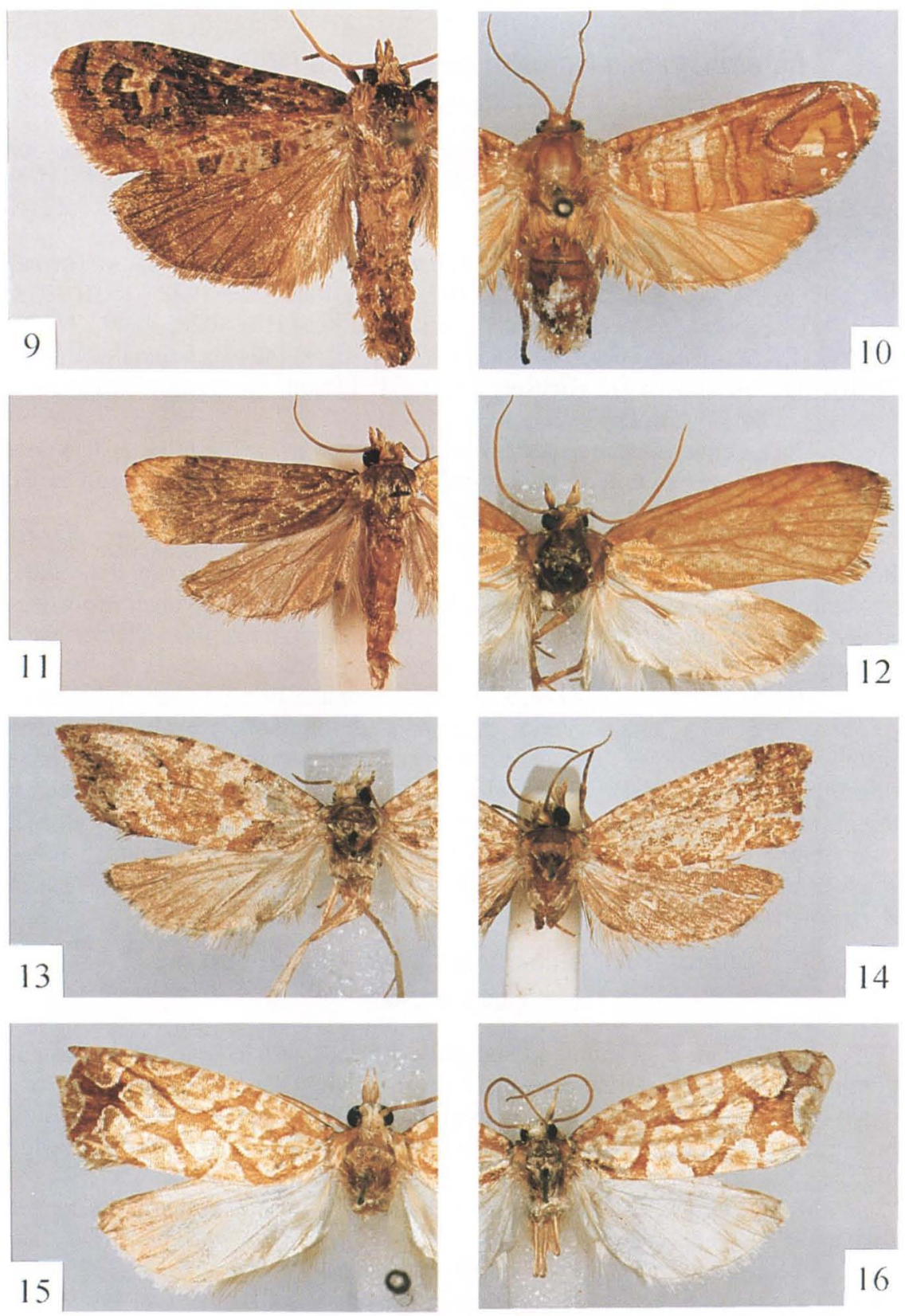

Figs 9-16. Adults of Auratonota and Heppnerographa. (9) A. hydrogramma, male, Costa Rica; (10) A. magnifica, male holotype, Venezuela; (11) A. aurantica, male, Costa Rica; (12) $A$. monochroma, male holotype, Ecuador; (13) $\mathrm{H}$. carchiana, male holotype, Ecuador; (14) $A$. oxytenia, male holotype, Mexico; (15) H. ardea, male holotype, Ecuador; (16) A. moronana, male holotype, Ecuador. 


\section{Auratonota spinivalva spinivalva ssp.n.}

Figs $3,43,44$

Wing span $19 \mathrm{~mm}$. Head white cream, yellower dorsally; labial palpi ca 3, with second segment scaled brown to before end laterally; thorax yellow-cream, with base of tegulae spotted brown. Fore wings ground colour cream suffused with brown except for edges of markings; markings dark brown, paler and more ochreous in dorsal half of median cell, more reduced than in A. petalocrossa; three antemedian, larger costal blotches and one postmedian blotch; first fascia extending from postbasal part of dorsum to middle of costa, distinctly concave subcostally, second fascia from beyond middle of dorsum to before apex, fusing with subterminal fascia at $\mathrm{CuP}$; terminal area of ground colour narrow, convex proximally; cilia concolorous with suffusions of ground colour. Hind wings brownish, paler basally; cilia creamer, with difuse basal line.

Male genitalia (Figs 43, 44). Uncus long, slender, slightly broadening basally; socii slender at base; hami broadening terminally; distal third of valvae broad, rounded terminally, armed with thick spines; vinculum as in A. petalocrossa. Aedeagus weakly sclerotized; a sclerotized band armed with minute spines in vesica.

Holotype male. MeXICo: Chiapas, Villa las Rosas, 1300 m, 27.VI.1981 (Becker) [43477] G. S. 21883. Paratype male. MEXICO: Chiapas, Teopisca 1900 m, 23-26.VI.1981 (Becker) [43249, 43250] (VOB).

Remarks. The above description is based on the nominative subspecies.

\section{Auratonota spinivalva cubana ssp.n.}

Figs $4,45,46,112$

Wing span 18-19 mm. Head creamy; labial palpi 3, pale brownish grey, cream dorsally; thorax brownish grey, base of tegulae yellowish brown, edges creamy. Fore wings ground colour glossy white near markings, distinctly suffused ochreous or yellowish brown in median areas; markings brownish ochreous, median fasciae yellowish brown, dorsal area and along basal half of costa brown; cilia whitish, divisions broad, brownish yellow. Hind wings brownish, darker on margins; cilia creamy with brownish basal line.

Variation. One specimen with dark, brown forewing markings, another with two blotches brown, much darker than the remaining maculation.

Male genitalia (Figs 45, 46). Hami slender, as long as uncus; uncus weakly expanding terminally; socii slender. Vinculum with rather uniformly broad saccus, rounded terminally; distal third of valvae broadening, spined.

Female genitalia (Fig. 112). Lobes of sterigma slender; colliculum broad, tapering towards ductus bursae, rather well sclerotized in distal half. Signum more elongate than in both preceding species.

Holotype male. CuBA: S[an]t[ia]go, Sier[ra] Maestra, P.[ico] Cuba, 1500 m, 31.VII.1990, (Becker) [73577], G.S. 21880. Paratypes. 2 males, two females: Same data (VOB, ISEZ). 

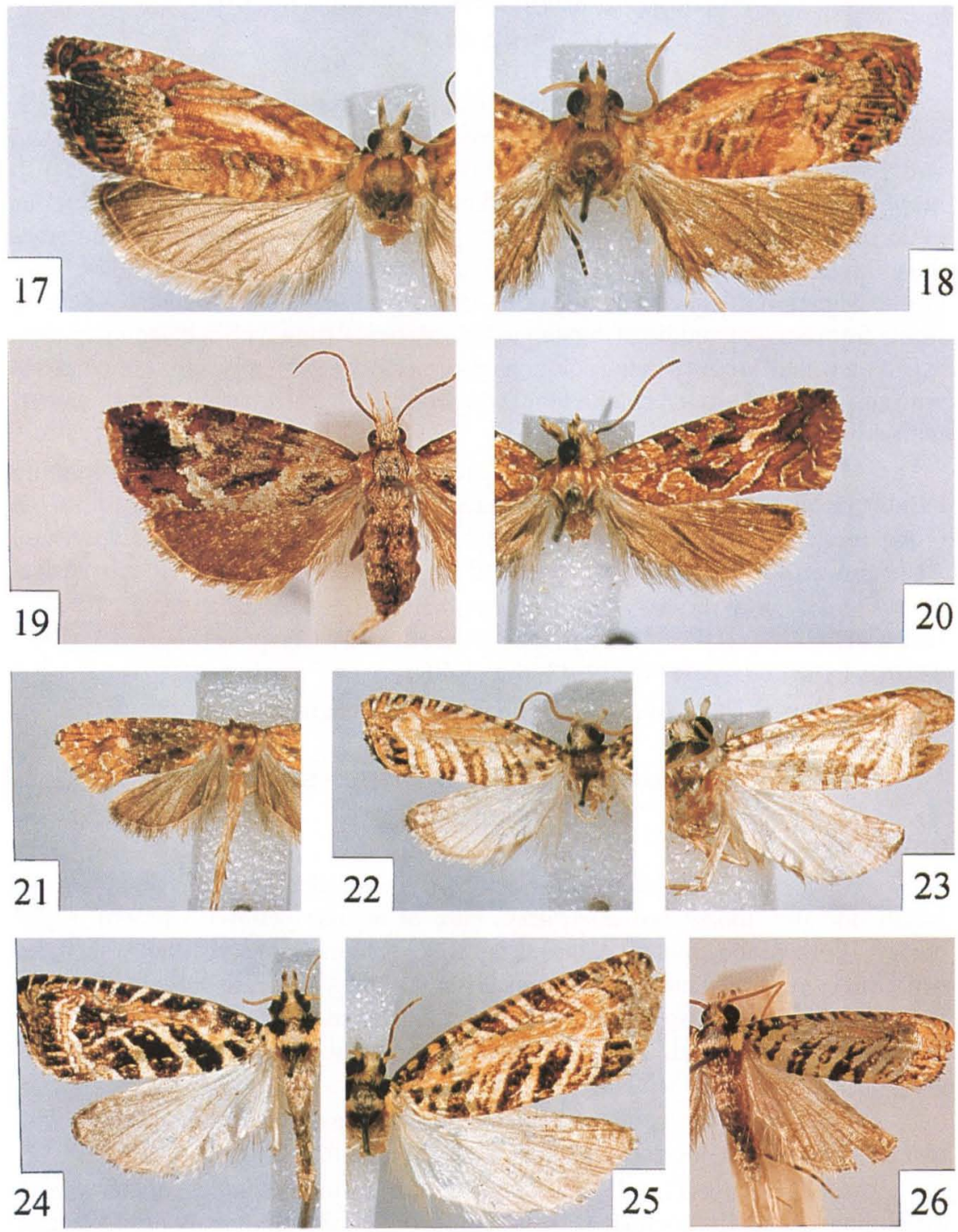

Figs 17-26 Adults of Auratonota. (17) A. virgata, female paratype, Ecuador; (18) A. tessellata, male holotype, Brazil; (19) A. badiaurea, female holotype, Brazil; (20) A. auriginea, female paratype, Brazil; (21) A. effera, male holotype, Mexico; (22) A. nugax, male holotype, Ecuador; (23) A. foederata, male holotype, Ecuador; (24) A. cataponera, male holotype, Ecuador; (25) A. splendida, male holotype, Ecuador; (26) A. dispersa, male, Costa Rica. 


\section{Auratonota serotina sp.n.}

Figs $5,47,48,113$

Wing span $20 \mathrm{~mm}$; head white-cream, tinged yellowish in female, labial palpi over 3; thorax concolorous with head, tinged yellow-ochreous proximally (basal half of tegulae) and distally. Fore wings ground colour glossy cream along markings edges, otherwise golden-ochreous; markings blackish brown, ochreous in tornal area and at $\mathrm{PCu}$, similar in shape to that in $A$. spinivalva, but the terminal area of ground-colour much broader, convex proximally. Otherwise as in former species, but hind wings paler.

Male genitalia (Figs 47, 48). Similar to those of $A$. spinovalva but uncus shorter, slightly slenderer medially, with shorter basal broadening; socii much smaller; hami shorter, as long as uncus, slightly expanding terminally; saccus broad; valvae slenderer in basal third, with larger area of spines. Aedeagus with much broader belt of spines than in former species, with short coecum penis.

Female genitalia (Fig. 113). Similar to those of $A$. hydrogramma but with large, scobinate plate beyond sterigma, and shorter, somewhat stronger sclerotized colliculum; signum longer, with much smaller spines; small sclerite near base of ductus seminalis.

Holotype male. Mexico: Tam[aulipas], Gomes Farias 1000 m, 2931.VII.1988 (Becker \& Solís) [69806], G.S. 21911. Paratypes. 1 male, 2 females: Same data (VOB).

Remarks. The paratype male show some variation in the male genitalia (Figs $49,50)$, especially in size of spines on valvae and uncus.

\section{Auratonota hyacinthina (Meyrick, 1912), comb.n.}

Cnephasia hyacinthina Meyrick, 1912b: 682. Holotype male, CoLOMBIA: San Antonio, 5,800 ft XI.1907 (BMNH) [examined].

Eulia hyacinthina; Clarke, 1958: 128, pl. 62, figs 2a-2b.

Known from holotype only. On basis of similarity of uncus, socii and hami it is included in Auratonota. However, the fore wing markings are different, with dorsal fasciae missing.

\section{Auratonota paidosocia sp.n.}

\section{Figs $6,51,52$}

Wing span ca $14 \mathrm{~mm}$. Head olive cream; labial palpi ca 2.4 , with brown suffusion at end of median joint; thorax darker than head, base of tegulae mixed brown. Fore wings narrower than those of $A$. serotina, slightly expanding terminally, with shorter termen; ground colour golden olive, silvery along edges of markings; markings, at least in median half of wings brownish, irrorated olive, glossy; cilia paler than ground colour. Hind wings pale brownish grey, with some creamy dots; cilia white creamy, basal line pale brownish.

Male genitalia (Figs 51,52). Similar to those of $A$. serotina but base of uncus distinctly broad; slender terminal portion short. Valvae uniformly broad throughout. Aedeagus slender resembling that in A. serotina but much shorter, cornuti absent. 

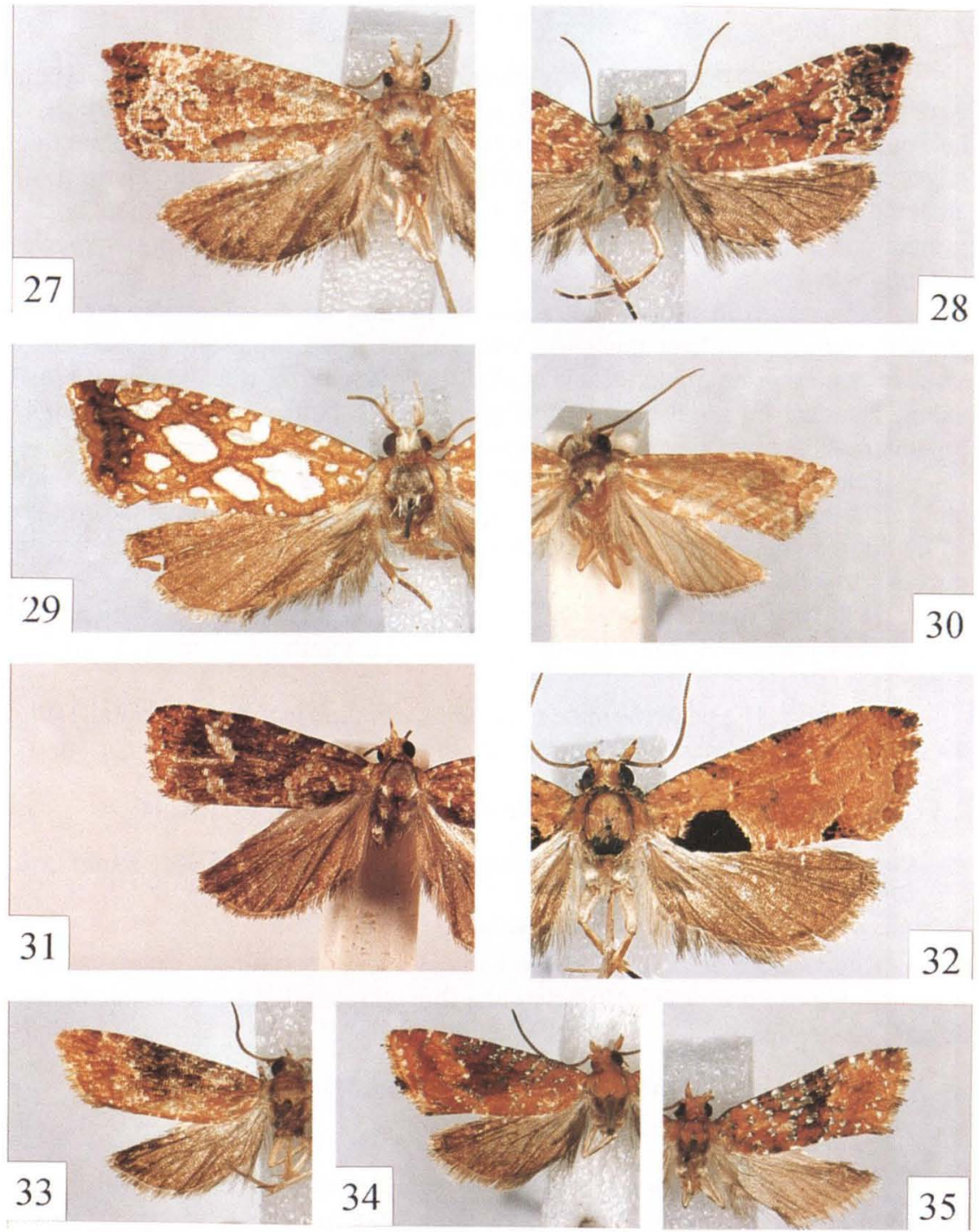

Figs 27-35. Adults of Auratonota, Monortha and Heppnerographa. (27) A. clasmata, male holotype, Brazil; (28) A. exoptata, male holotype, Brazil; (29) H. tricesimana, female, Ecuador; (30) H. arammclaina, male, Costa Rica; (31) A. omorpha, female holotype, Costa Rica; (32) M. funesta, male, Brazil; (33) H. lapilla, male holotype, Brazil; (34) H. brasiliana, male holotype, Brazil; (35) H. ecuatorica, male holotype, Ecuador. 
Holotype male. CuBA: S[an]t[ia]go, Sier[ra] Maestra P.[ico] Cuba 1500 m, 31.VII.1990, (Becker) [73578], G.S. 21876. Paratype male. Same data (VOB).

Remarks. Externally similar to A. serotina but differing in lack of ochreous suffusion of ground colour on dorsum of fore wings and in the genitalia. Female unknown.

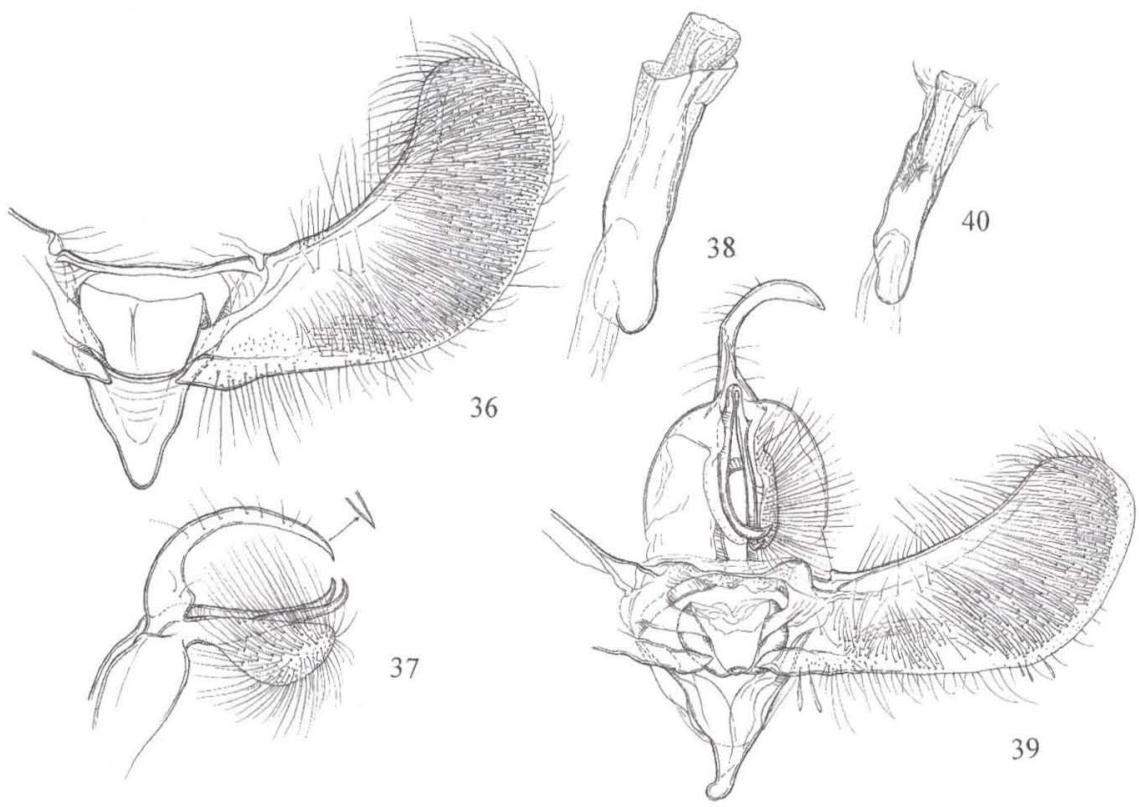

Figs 36-40 Genitalia of Auratonota males. (36-38) A. hydrogramma (Meyrick), Costa Rica; (39-40) A. petalocrossa petalocrossa (Meyrick), Costa Rica.

\section{Auratonota aurantica (Busck, 1920)}

Figs $11,53,54$

Epagoge aurantica Busck, 1920: 84. Syntype male, CosTA RiCA: Juan Viñas (Schaus) (USNM) [examined].

Auratonota aurantica; Razowski, 1987: 62, figs 1,2.

Material examined. One male, CosTA RICA: Turrialba, 600 m, 20.XII.1971 (Becker) [55974]; 4 males, Bráulio Carrillo, 1100 m, VII.1981 (Becker) [44799] (VOB).

Male genitalia described by RAZOWSKI (1987) on basis of preparation from a specimen in BMNH. The present examination allows an important correction as the socii in this species are submembranous, very long and the proportions of the broad and slender terminal parts of uncus are different as the latter is longer (Figs $53,54)$. Female unknown. 


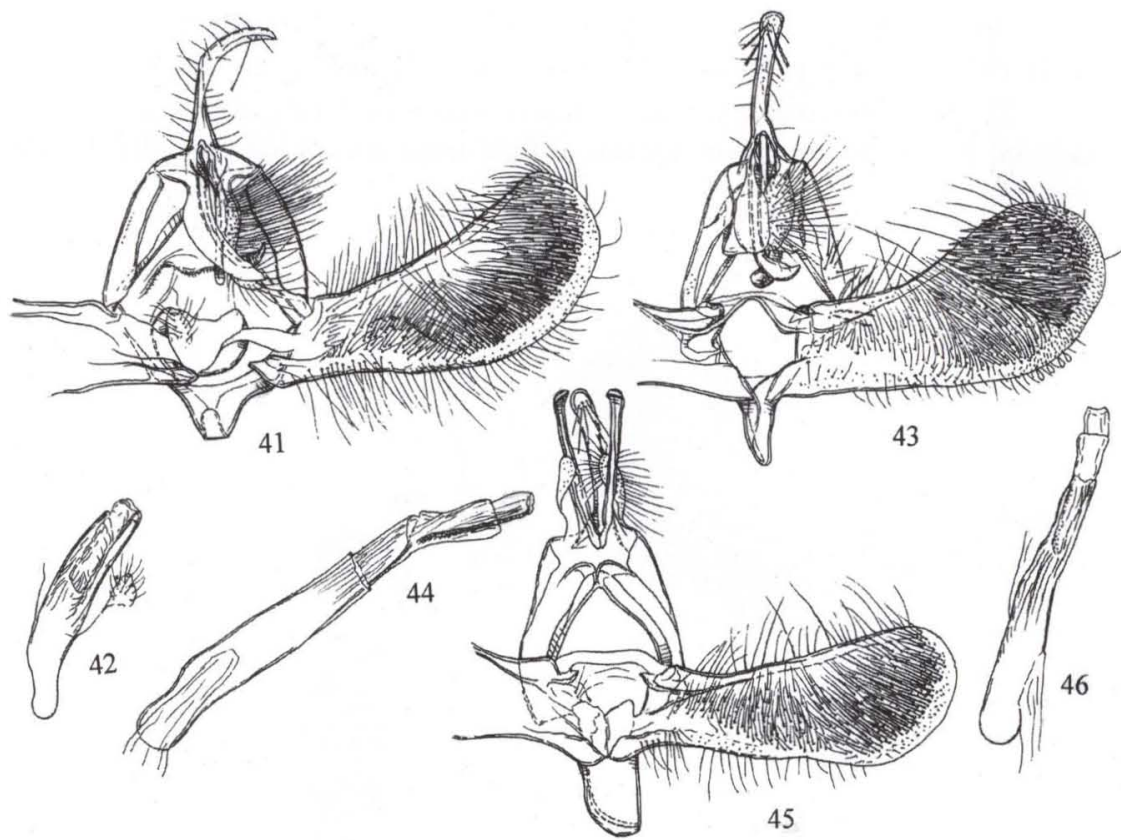

Figs 41-46 Genitalia of Auratonota males. (41-42) A. petalocrossa maldonada ssp.n., holotype, Ecuador; $(43,44)$ A. spinivalva spinivalva ssp.n., holotype, Mexico; (45-46) A. spinivalva cubana ssp.n., holotype, Cuba.

\section{Auratonota multifurcata (Meyrick, 1932), comb.n.}

Eulia multifurcata Meyrick, 1932: 260. Holotype male, CosTA RicA: Poás, 2150m, IV.1930 (Reimoser) (NHMW) [examined].

Eulia multistrigata Razowski, 1964: 461, figs 25,26, misspelling.

Eulia multifurcata; Razowski, 1990: 400.

Tentatively placed near A. aurantica based mainly on similarity of uncus. The socii and the hami are rather similar to those of other species in the group, and the slender aedeagus is known in several species (e.g. A. oxytenia).

\section{Auratonota stigmosa sp.n.}

Figs $7,55,56$

Very similar to A. serotina but bifurcation of distal markings of fore wings much shorter and basal half of hind wings creamy.

Male genitalia (Figs 55, 56). Uncus thinner than that of $A$. serotina, aedeagus larger, with longer ventral sclerite, saccus twice as thin as in A. serotina, tapering at distal half.

Holotype male. ECUADOR: Carchí, Maldonado, 2200 m, 9-11.I.1993 (Becker) [105232], G.S. 21897. 
Remarks. Another male (ECUADOR: Loja, 2750 m, 21.XII.1992 (Becker) [103146]), differs slightly from holotype in genitalia and is not included in the type-series.

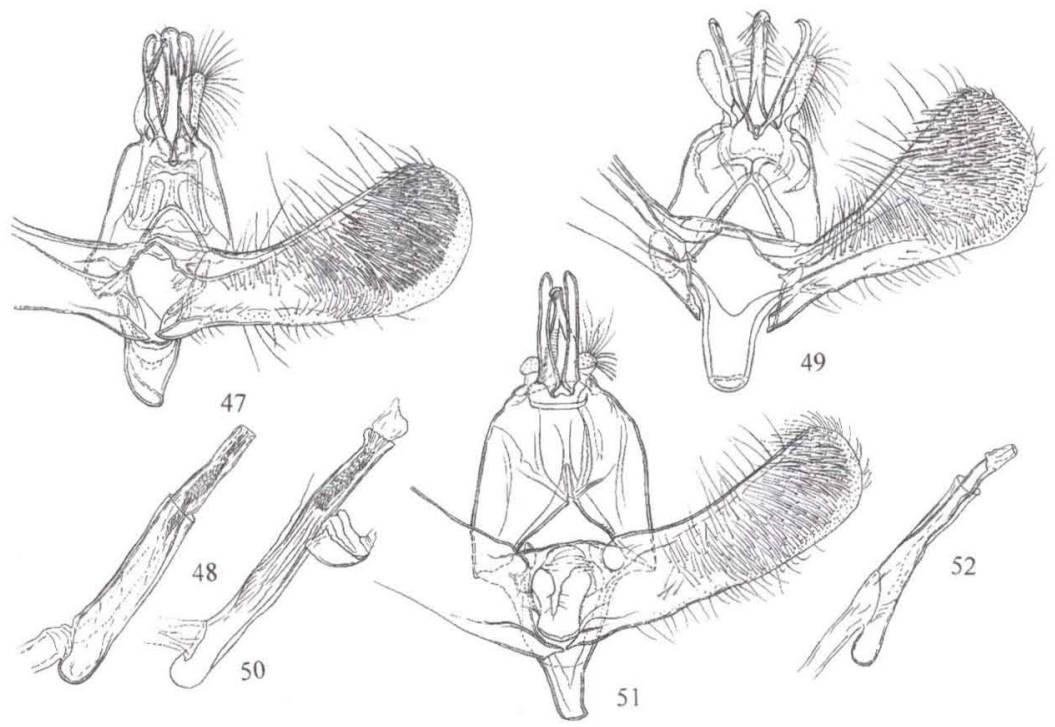

Figs 47-52. Genitalia of Auratonota males. (47-48) A. serotina sp.n., holotype, Mexico; (49-50) A. serotina sp.n., paratype, Mexico; $(51,52)$ A. paidosocia sp.n., holotype, Cuba.

\section{Auratonota effera sp.n.}

Figs $21,57,58$

Wing span $11 \mathrm{~mm}$; head cream; thorax golden yellow. Fore wings somewhat expanding terminally, with costa slightly convex at base, apex broad, termen oblique, almost straight; ground colour golden yellow, slightly mixed ochreous, especially in basal area, glossy cream along edges of markings; markings less glossy, golden ochreous, with brownish edges, consisting of two dorsal fasciae in median area connected to two costal fasciae inside median cell; posterior fascia with pale, ovate spot beyond the fusion area, followed by a prominence connected to subterminal fascia; the latter with posterior edge concave between apex and M3; cilia creamer than ground colour, with a few brownish divisions at apex and postmedially. Hind wings brownish with paler base and cilia.

Male genitalia (Figs 57, 58). Uncus distinctly expanding in distal third, rounded apically; socii fairly broad; hami near as long as uncus; vinculum very slender. Valvae narrow in basal half, broad, rounded caudally; aedeagus rather slender, simple.

Holotype male. Mexico: Tam[aulipas], Gómez Farias, 1000m, 2931.VII.1988 (Becker \& Solís) [69805], G.S. 21914. 
Remarks. The smallest species in the genus, distinguished from others by the coloration and, in male genitalia, by very narrow vinculum.

\section{Auratonota monochroma sp.n.}

Figs $12,59,60$

Wing span $25 \mathrm{~mm}$. Head yellowish; labial palpi ca 2, browner laterally. Fore wings slightly expanding terminally, with apex rounded, termen weakly oblique, plain shining golden ochreous; cilia paler, yellow, with difuse, more ochreous divisions. Hind wings creamy in basal part, ochreous in distal third, darkening along edges; cilia creamy.

Male genitalia (Figs 59,60). Uncus narrow in distal fourth; hami broadest postbasally; socii slender, slightly shorter than hami; saccus large, broad. Valvae rather uniformly broad throughout, rounded terminally; sacculus broad. Aedeagus small, slender, tapering distally.

Holotype male. EcuADOR: Carchí, Maldonado, 2200 m, 9-11.I.1993 (Becker) [105234], G.S. 21879.

Remarks. Easily distinguished by absence of markings and uniformely broad distal portion of valvae. Labial palpi rather short, resembling those of A. petalocros$s a$, but the socii are thinner.

\section{Auratonota oxytenia sp.n.}

Figs 14, 61, 62

Wing span ca $16 \mathrm{~mm}$; head yellowish cream, with vertex an labial palpi (ca 2.5) more ochreous; thorax yellowish brown, distal part of tegulae creamy. Fore wings expanding terminally, with sharp apex and rather oblique termen; fasciae of ground colour pale brownish, glossy white along edges of markings; markings brownish, diffuse; cilia creamer than ground colour, with basal line brown. Hind wings brownish with creamer cilia.

Male genitalia (Figs 61, 62). Uncus broad, as long as hami; socii slender, half length of hami. Vinculum with very large saccus provided with small, thin termination. Valvae narrow. Aedeagus very thin, very long, with long dorso-terminal projection.

Holotype male. MEXICO: Chiapas, Teopisca, 1900 m, 23-26.VI.1981 (Becker) [43250], G.S. 21877. Paratype male. Same data (VOB).

Remarks. Markings typical of the majority of the representatives of this genus (e.g. A. spinivalva, A. stigmosa) but rather diffuse (specimen slightly descaled). Distinguished by sharp apex of fore wings and very long aedeagus.

\section{Auratonota moronana sp.n.}

Figs $16,63,64$

Wing span $22.5 \mathrm{~mm}$. Head creamy white; labial palpi ca 3, creamy, sprinkled brownish laterally; thorax brownish cream, tegulae glossy yellow with yellowish brown basal blotch. Fore wings broad, with short, sharp apex and fairly oblique, straight termen; ground colour whitish, with shining dots and pale ferruginous 
median suffusions; markings pale ferruginous with rust suffusions connecting one to another to form an incomplete net; its most distinct element is the subterminal blotch with five fasciae extending from a rounded blotch; cilia (partially destroyed) whitish cream. Hind wings creamy white, tinged yellowish terminally; cilia paler.

Male genitalia (Figs 63, 64). Uncus broad, much shorter than hami; hami curved; socii half length of uncus; vinculum with saccus tapering terminally, slender in distal third. Valvae slightly broadening in distal third. Aedeagus small, shorter than costa of valvae, somewhat curved medially.

Holotype male. ECUADOR: Morona, Indanza, 2800 m, 24.XII.1992 (Becker) [103482], G.S. 21878.

Remarks. Distinguished by coloration of fore wings. Male genitalia resembles those of $A$. oxytenia but easily distinguished by long socii and much smaller saccus.

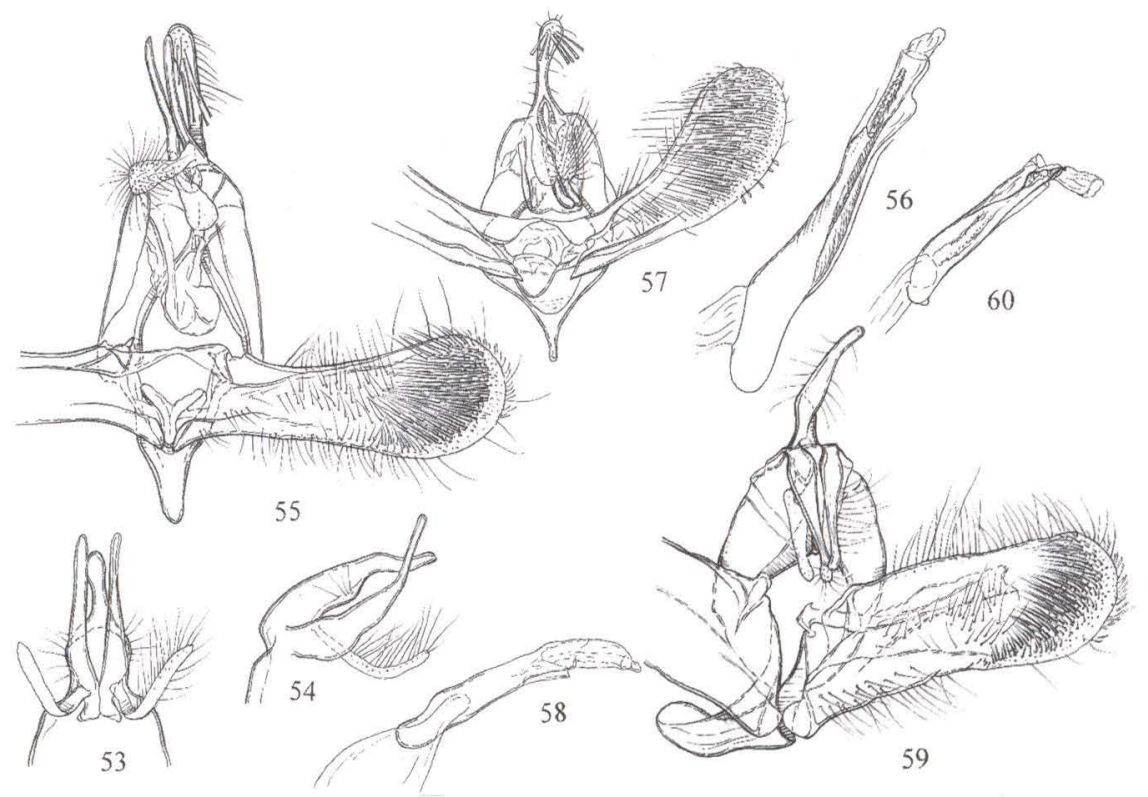

Figs 53-60. Genitalia of Auratonota males. (53-54) A. aurantica (Busck), Costa Rica; (55-56) A. stigmosa sp.n., holotype, Ecuador; (57-58) A. effera sp.n., holotype, Mexico; (59-60) A. monochroma sp.n., holotype, Ecuador.

\section{Auratonota virgata sp.n.}

Figs $17,65,66,114$

Wing span 18-20 mm. Head greyish cream, front whitish, vertex fuscous; labial palpi over 2, broadened and laterally suffused brownish at end of second segment; thorax brownish ochreous, distal part of tegulae creamy. Fore wings weakly expanding terminally, apex broad, rounded; termen weakly oblique, 
straight; ground colour in form of a creamy fascia from base to end of radial arm of median cell and with somewhat darker strigulation in dorsal area, otherwise strongly suffused rust; grey suffusion in distal third extending from end of median cell; costal strigulae cream divided grey, rust and orange; rust divisions brown at costa; orange dots in grey area; ocellus orange rust with black strigulae, edges with glossy grey fascia; dorsum strigulate brown or grey, in type with some cream dots; cilia brownish with irrorated grey and cream scales, divisions browner, diffuse. Hind wings brownish grey, paler basally, cilia concolorous with mid part of wing.

Male genitalia (Figs 65, 66). Uncus slender; hami shorter than uncus, with sharp, ventral prominence terminally; socii large, broad. Valvae fairly broad, not expanding terminally; distinct dentate prominence at end of sacculus. Saccus broad, longer than sacculus. Aedeagus approximately as long as costa of valvae.

Female genitalia (Fig. 114). Papillae anales moderate; colliculum fairly broad, slightly tapering in proximal scobinate portion; lobes of sterigma distinct. Ductus bursae long, very slender; ductus of accessory bursa very long; signum long.

Holotype male. EcuAdor: Carchí, Maldonado, 2200 m, 9-11.I.1993 (Becker) [105326], G.S. 21889. Paratypes. 1 male, 2 females: Same data; 1 female, ECUADOR: Past[aza], Mera. XII.1992 (Becker) [100679] (VOB, ISEZ).

Remarks. This and $A$. tessellata are easily distinguished by forewing coloration which resembles that on Hilarographini species. Male genitalia characterized by thin socii and distinct prominence of end of sacculus.

\section{Auratonota tessellata sp.n.}

Figs $18,67,68$

Wing span $17 \mathrm{~mm}$. Head brownish grey; labial palpi over 2, creamy beneath, blackish terminally; thorax yellowish brown. Fore wings broader than in $A$. virgata with more curved costa and less oblique termen; coloration as in that species but radial streak smaller and dorsum paler, ochreous orange, suffused grey in basal half, with several whitish cream lines; terminal area greyer than in A. virgata, ocellus edged black at tornus. Hind wings rather dark, brownish; cilia slightly paler.

Male genitalia (Figs 67, 68). Uncus very broad, tapering apically; hami short, vedge-shaped; socii broad, ovate; saccus very broad, rounded apically. Valvae narrow, with small prominence at the end of sacculus. Aedeagus moderate.

Holotype male. BRAZIL: S[ão] P[aulo], Jacupiranga, 800 m, 8.II.1993 (Becker) [87544], G.S. 21896.

\section{Auratonota flora sp.n.}

Figs $8,69,70$

Wing span ca $19 \mathrm{~mm}$; head creamy, vertex slightly suffused ochreous; labial palpi over 2. Fore wings weakly expanding terminally, with costa straight, apex very short, sharp; termen straight; markings typical of the tribe (e.g. as in A. strigosa, A. spinivalva) but orange brown, in distal half finely edged black; costal strigulae and ground colour reduced to white or silvery dots; the inner areas being almost concolorous with markings; cilia orange. Hind wings dark dull brown; cilia slightly paler. 
Male genitalia (Figs 69, 70). Uncus and hami long; socii broad, ovate; saccus short, broad terminally. Valvae proportionally short, simple, rounded caudally. Aedeagus small, slender.

Holotype male. ECUADOR: Tung[urahua], Rio Verde, 1600 m, 26.XII.1992 (Becker) [104056], G.S. 21882.

Remarks. Externally rather similar to $H$. tricesimana chiefly in the series of silvery dots of fore wings. Easily distinguished by broad socii and long, sharp hami.

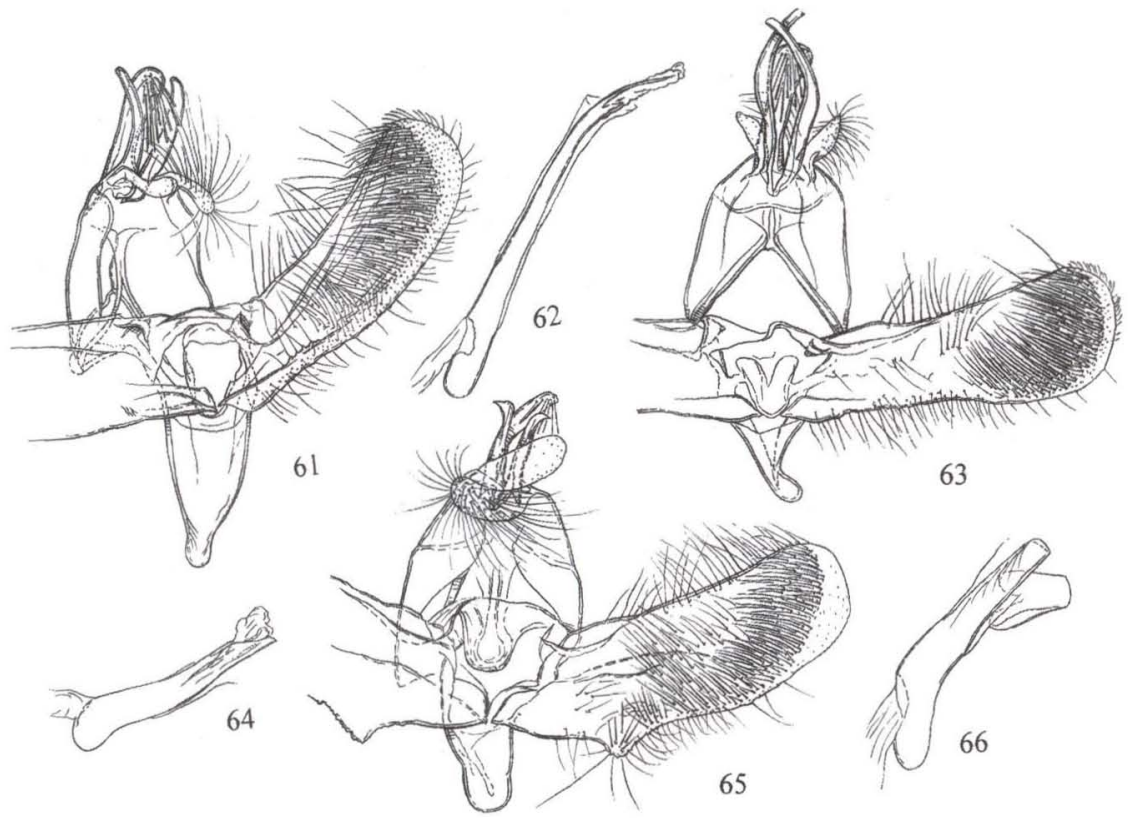

Figs 61-66. Genitalia of Auratonota males. (61-62) A. oxytenia sp.n., holotype, Mexico; (63-64) A. moronana sp.n., holotype, Ecuador; (65-66) A. virgata sp.n., holotype, Ecuador.

\section{Auratonota exoptata sp.n.}

Figs $28,71,72$

Wing span $15 \mathrm{~mm}$ (in paratype $13 \mathrm{~mm}$ ); head white, vertex suffused ochreous, labial palpi ca 2, rusty medially; thorax ochreous, base of tegulae browner. Fore wings slightly expanding terminally, apex rather short, sharp, termen somewhat oblique, sinuate; ground colour strongly suffused brown; markings darker, edged silver mainly in distal half where black strigulae are present; cilia brownish, with brown basal line. Hind wings grey-brown, paler in basal third; cilia rather concolorous, with median line darker.

Male genitalia (Figs 71, 72). Uncus and hami broad, equally long; socii large, broad, rounded apically; saccus broad. Valvae broad, ovate; sacculus simple, convex medially. Aedeagus slightly longer than lengh of valvae. 
Holotype male. BrazIL: M[inas] G[erais], Caraça, 1300 m, 25.X.1994 (Becker \& Sattler) [93560], G.S. 21906. Paratype male. Same data (VOB).

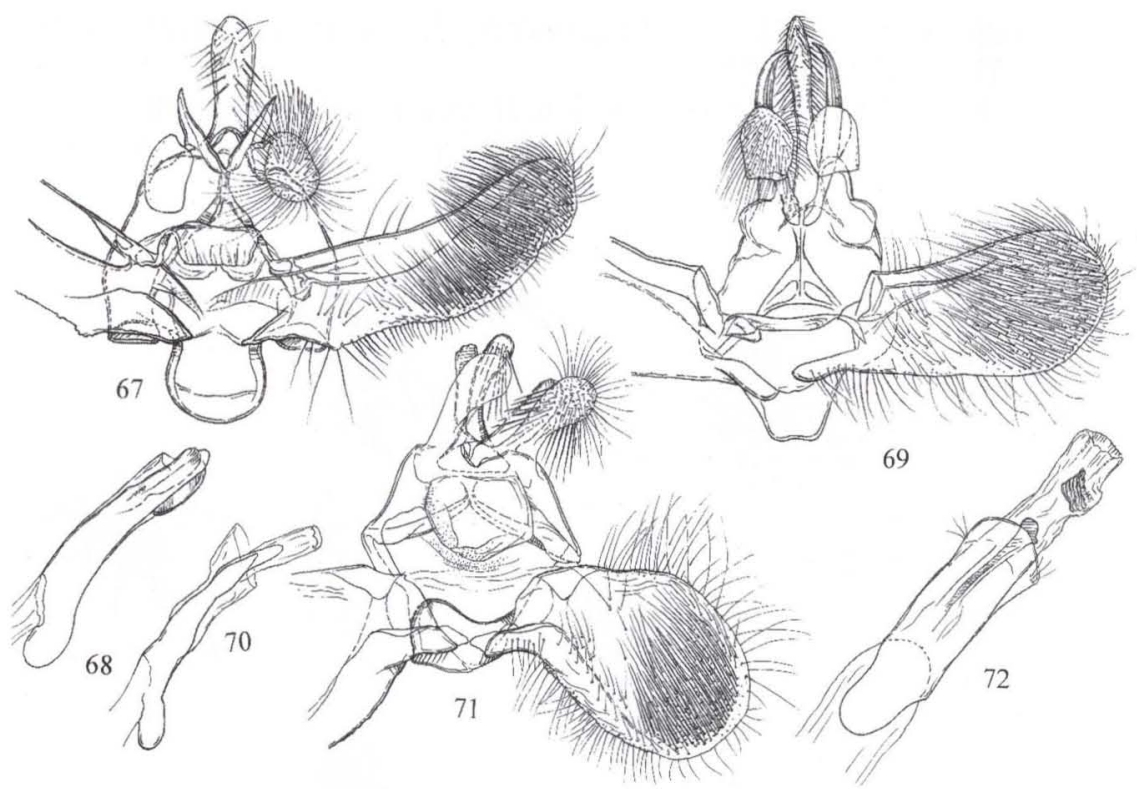

Figs 67-72. Genitalia of Auratonota males. (67-68) A. tessellata sp.n., holotype, Brazil; (69-70) A. flora sp.n., holotype, Ecuador; (71-72) A. exoptata sp.n., holotype, Brazil.

\section{Auratonota clasmata sp.n.}

Figs $27,73,74$

Wing span ca $16 \mathrm{~mm}$. Head cream, front whitish, vertex tinged ochreous; labial palpi ca 2, dirty cream with pale brownish dots, terminal segment short, cream; thorax whitish scaled ochreous collar, basal half of tegulae and distal part of thorax yellowish brown. Fore wings distinctly expanding distally, with termen weakly oblique, slightly sinuate; ground colour glossy whitish, contrasting, especially near markings, suffused pale ochreous medially; markings yellowish brown, dotted black especially along edges in distal half, with fasciae rather diffuse except for the median; some fasciae interrupted, the subterminal one consisting of dots; cilia concolorous with markings, with some cream places. Hind wings brownish; cilia creamer with brownish basal line.

Male genitalia (Figs 73, 74). Uncus slender, expanding in distal half; socii broad, narrow basally; hami situated beneath the latter, weak, flat. Valvae narrow basally, very broad, rounded, with long bristles and spined in distal half. Aedeagus stout; coecum penis fairly large; ventral sclerotized band marked with subterminal thorn; cornuti absent. 
Holotype male. BRAZIL: M[inas] G[erais], Nova Lima, 850 m, 30.XII.1988 (Becker) [60547], G.S. 21913.

Remarks. This and the former species are very similar in coloration having somewhat different markings of those typical to the genus. In the male genitalia they are similar in the shape of valvae and in weak sclerotization of base of socii.

\section{Auratonota dispersa J.W. Brown, 1990 \\ Figs $26,75,76$}

Auratonota dispersa J.W. Brown, 1990a: 154, figs 1,2. Holotype male, Panama: Cocle, El Valle, 22.IV.1965 (S. \& D. Duckworth) (USNM) [examined].

Material examined. Two males from CosTA RICA: Braulio Carrillo, VII.1981 (Becker) [44800] (VOB).

Described from type-locality, several provenances of Costa Rica, one male from Miami, Florida and one specimen collected in Miami, associated with orchids imported from Guatemala. Males show some external differences in the shape of the dorsal fasciae of the forewing but the genitalia seem identical. More accurate drawings than those given originaly and description of genitalia are as follows.

Male genitalia (Figs 75, 76). Uncus weakly expanding terminally; socii broad, rigid, tapering apically; hami slender, longer than socii; gnathos submembranous. Valvae rather uniformly broad, rounded caudally; transtilla rather membranous. Aedeagus very slender, long, with long, curved coecum penis; long, slender sclerite in wall of vesica and very thin anterior cornutus; posterior series consisting of short, rather thick spines followed by three longer ones.

\section{Auratonota aenigmatica (Meyrick, 1912)}

Cnephasia aenigmatica Meyrick, 1912b: 682. Holotype male, ColomBIA: San Antonio, $5800 \mathrm{ft}$ XI.1907 (BMNH) [examined].

Hilarographa aenigmatica; Heppner, 1982: 711.

Auratonota aenigmatica; Razowski, 1987: 62; J.W. Brown, 1990a: 156.

Very similar to $A$. dispersa but differing by strongly suffused inner gaps (represented by some pale dots only) between dorsal pairs of fasciae. The setae of venter of uncus in A. dispersa mentioned by Brown (1990a: 156) are in fact thin scales which may easily break off. They are not found in this species.

\section{Auratonota splendida sp.n.}

Figs $25,77,78$

Wing span $23.5 \mathrm{~mm}$. Similar to A. aenigmatica but fore wings broader, with longer, slightly straight termen; markings broader; dorsal fasciae not reaching middle of wing.

Male genitalia (Figs 77, 78). Similar to those of $A$. dispersa but uncus uniformly broad and cornuti of same length.

Holotype male. ECUADOR: Tung.[urahua], Patate, 3000 m, 7.XII.1992 (Becker) [100133], G.S. 21894. 


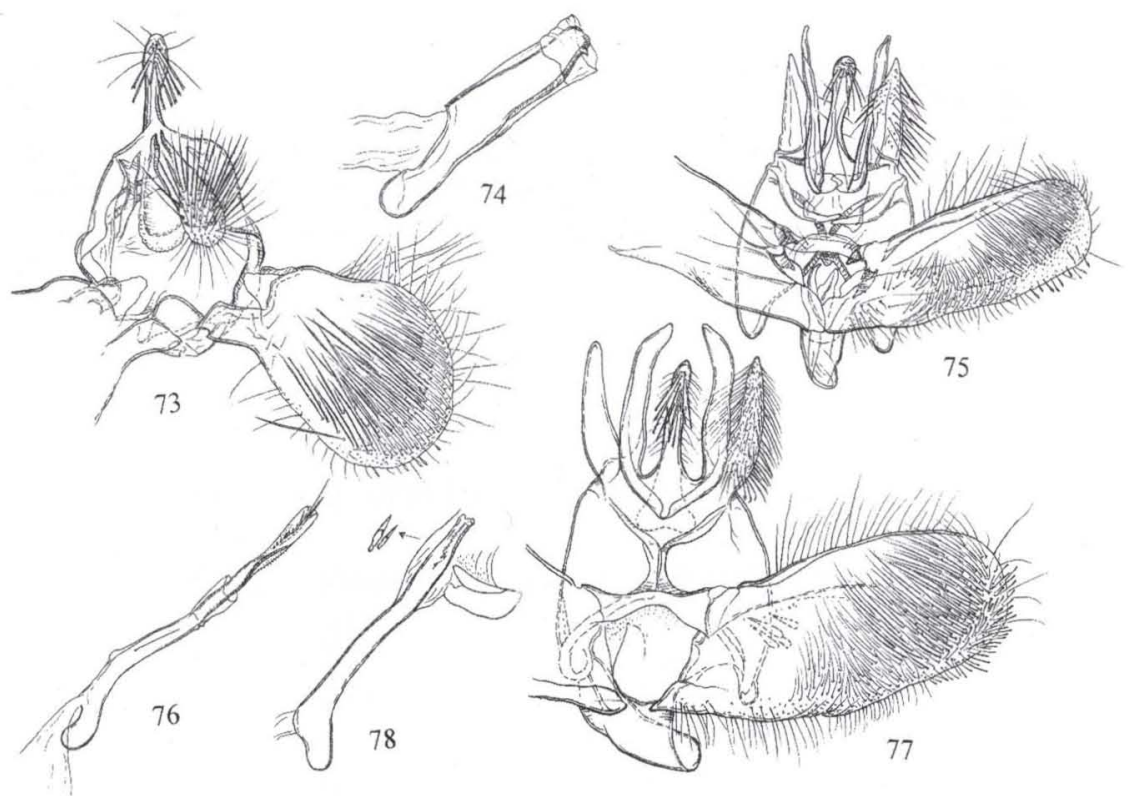

Figs 73-78. Genitalia of Auratonota males. (73-74) A. clasmata sp.n., holotype, Brazil; (75-76) A. dispersa (Brown), Costa Rica; (77-78) A. splendida sp.n., holotype, Ecuador.

\section{Auratonota cataponera sp.n.}

Figs $24,79,80$

Wing span $18 \mathrm{~mm}$. Externally similar to $A$. splendida but fore wings narrower and fasciae blackish brown, broad, dotted yellowish; third dorsal fascia convex posteriorly, reaching base of last two radial veins.

Male genitalia (Figs 79, 80). Uncus somewhat broadening subterminally. Valvae slenderer in basal third. Aedeagus much larger than that of A. splendida; cornuti, a large group of small spines.

Holotype male. ECUADOR: Loja, 2750 m, 21.XII.1992 (Becker) [103147], G.S. 21900. Paratypes. 1 male, same data; 2 males; ECUADOR: Carchí, Maldonado, 2200 m, 9-11.I.1993 (Becker) [105235] (VOB).

\section{Auratonota nugax sp.n.}

Figs $22,81,82$

Wing span $11 \mathrm{~mm}$. Pale with weak, brown-grey base of tegulae. Fore wings narrow; costal half yellowish, dorsal half more creamy; dorsal fasciae distinctly divided longitudinally with more ochreous; ocellus grey, with three black dots. Hind wings pale brownish cream, more fuscous apically.

Male genitalia (Figs 81, 82). Similar to those of $A$. cataponera but end of saccus hardly convex and uncus thinner. 
Holotype male. ECUADOR: Past.[aza], Mera, 1300 m, XII.1992 (Becker) [100678], G.S. 21892).

Remarks. One female with identical data and similar markings, but remarkably larger $(17 \mathrm{~mm})$, might be its opposite sex.

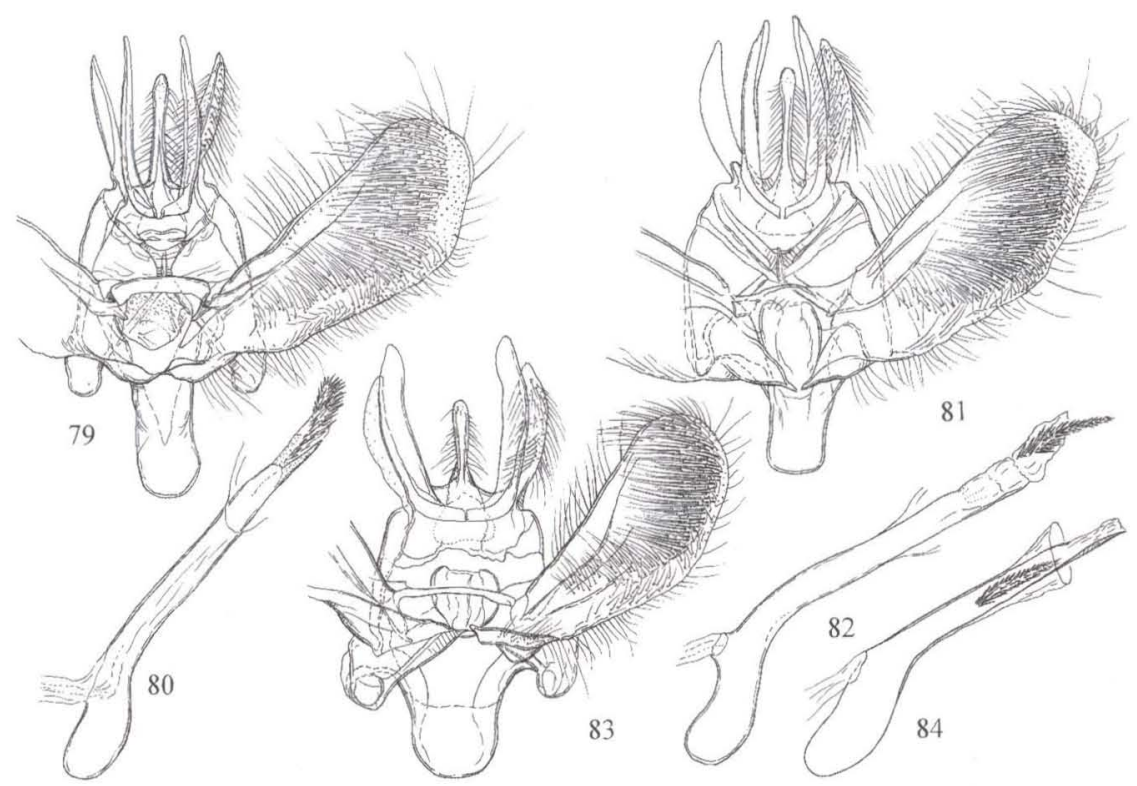

Figs 79-84. Genitalia of Auratonota males. (79-80) A. cataponera sp.n., holotype, Ecuador; (81-82) A. nugax sp.n., holotype, Ecuador; (83-84) A. foederata sp.n., holotype, Ecuador.

\section{Auratonota foederata sp.n.}

Figs $23,83,84$

Wing span $16 \mathrm{~mm}$. Externally resembling A. nugax.

Male genitalia (Figs 83, 84). Similar to those of $A$. nugax but base of uncus broad, aedeagus smaller, and saccus very broad, rounded apically.

Holotype male. ECUADOR: Tung.[urahua], Rio Verde, 1600 m, 26.XII.1992, (Becker) [103644], G.S. 21902.

\section{Auratonota dominica J.W. Brown, 1993}

Auratonota dominica J.W. Brown, 1993: 314, figs 1-3. Holotype male, DomINICA, $2.8 \mathrm{Km}$ E of Point Casse, 24.III.1965 (Wirth) (USNM) [not examined].

Known from Dominica, Lesser Antilles (West Indies) only.

Remarks. Originally (BROwN 1993) compared with A. aenigmatica and A. dispersa, however, their markings are different (with a series of narrow, double dorsal fasciae). 


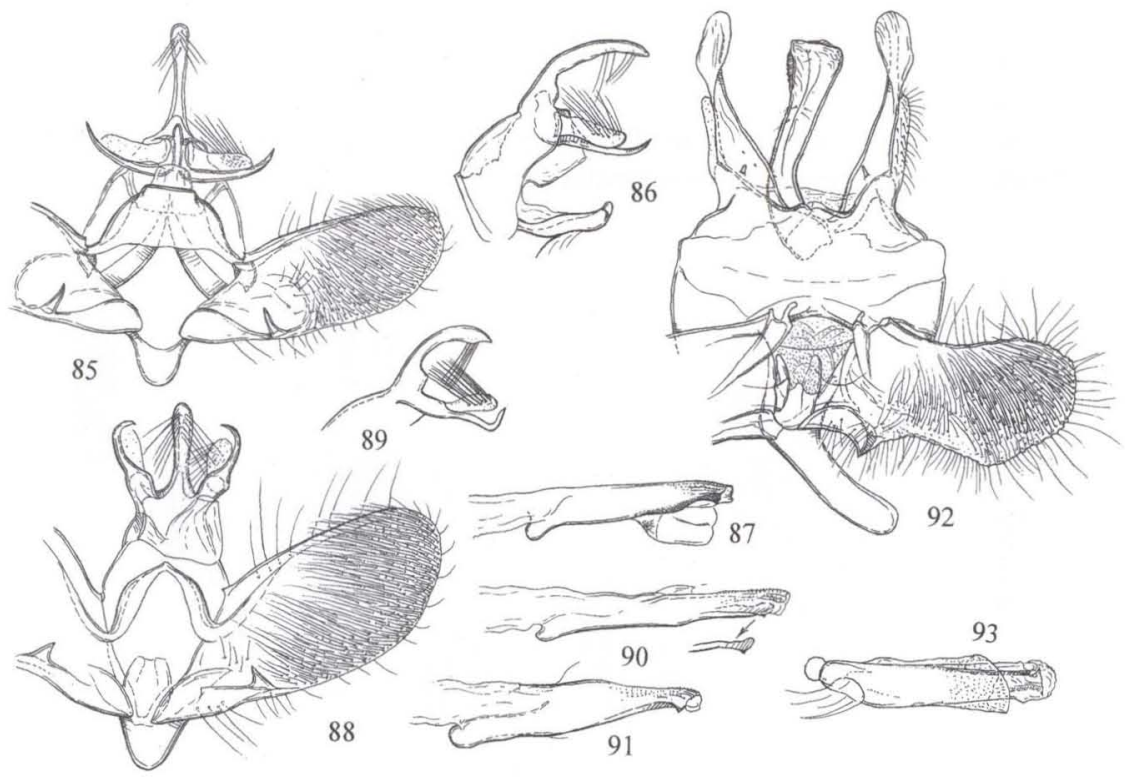

Figs 85-93. Genitalia of Auratonota males. (85-87) A. badiaurea sp.n., holotype, Brazil; (88-91) A. auriginea sp.n., holotype, Brazil; (92-93) A. magnifica sp.n., paratype, Venezuela.

\section{Auratonota badiaurea sp.n.}

Figs $19,85-87,115,116$

Wing span 18-23 mm (holotype $22 \mathrm{~mm}$ ). Labial palpi over 2, pale ochreous cream, suffused ochreous laterally, cream above; remaining parts of head whitish cream, flagellum brownish; thorax cream, with collar and almost whole tegulae ferruginous brown. Fore wings expanding terminally, somewhat more in male than in female; apex very short, termen not oblique, weakly convex; costal fold in male present, very narrow, vestigial; ground colour whitish cream, suffused ochreous or ferruginous brown, with paler and darker groups of scales consisting of broad triangular blotch extending from costa, tapering towards middle of dorsum and broad, irregular blotch in posterior third, connected with the former by a postmedian whitish fascia, marked black in middle; in tornal part of that blotch two coalescent small dots of ground colour; small pale dots along dorsum, often interrupted with brown; in costal portion similar brown filled dots in the area of median blotch; cilia concolorous, interrupted white cream. Hind wings fairly broad, brown; cilia cream brown, with weak basal line.

Male genitalia (Figs 85-87). Uncus slender, slightly expanding distally, weakly bent; socii rather broad, weakly expanding distally; hami slender, sharp, curved; valvae elongate, with disc concave above sacculus, the latter broadest basally, with large, acute process near end; transtilla very large, strongly expanding dorso-posteriorly, with protruding median portion; aedeagus thin, tapering and somewhat asymmetrical in terminal portion; coecum penis small. 


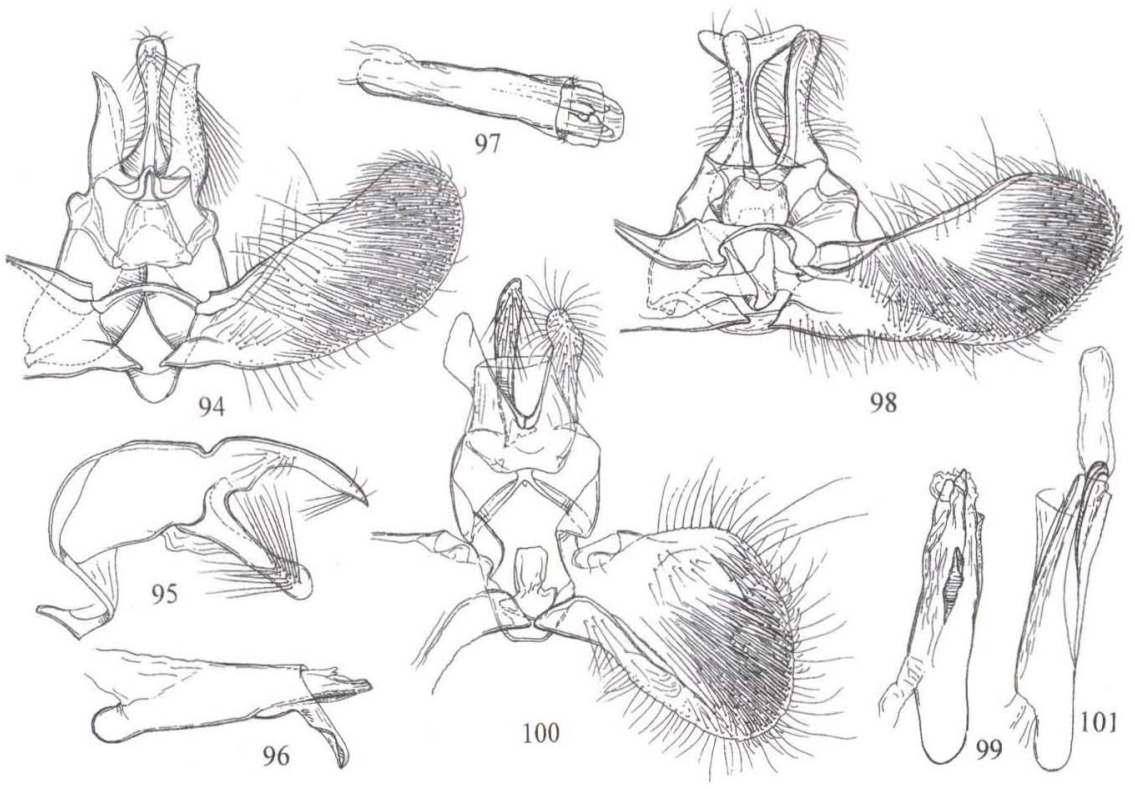

Figs 94-101 Genitalia of Heppnerographa males. (94-97) H. tricesimana (Zeller), Costa Rica; (98-99); H. ardea sp.n., holotype, Ecuador; (100-101) H. carchiana sp.n., holotype, Ecuador.

Female genitalia (Figs 115, 116). Papillae anales large, with very broad anterior part emarginate and expanded ventrally, terminal portion slender; ventral parts of eighth tergite connecting with small, scobinate ventral plate; sterigma rather short, with elongate lateral lobes; colliculum broad distally, expanding ventrad and distinctly sclerotized before end, tapering and scobinate anteriorly; remaining part of ductus bursae short, broadening towards corpus bursae; small sclerite at base of ductus seminalis; spines of signum long; accessory bursa with very long ductus.

Holotype female. BRAzIL: Paraná, Quatro Barras, Banhado, $800 \mathrm{~m}$, 28.XI.1970 (Becker) [14598]. Paratypes. 6 males, 8 females, 10 with same data as holotype; 3 from same locality, 27.XI.1970, 21.X.1971 (Becker \& Laroca) [14598, 34531, 34532, 34570], 1, Paraná, Morretes, Marumbi, 500 m, 16.XII.1969 (Becker) [14593] (VOB, ISEZ).

Remarks. Some specimens show some variation in size of markings and hue of ground colour, the inner parts of which may be more or less suffused; blackish suffusions or irroration in middle of terminal area more or less distinct. Distinguished externally by brown markings of the forewing and slight golden hue.

\section{Auratonota auriginea sp.n.}

Figs 20, 88-91

Wing span 14-18 mm (in holotype $15 \mathrm{~mm}$ ); labial palpi ca 2, distal half of second segment broad, yellowish cream, cream above, marked brown laterally; remaining parts of head yellowish cream to golden yellow, vertex often suffused brownish, flagellum brown; thorax darker and more shining than head, somewhat 
browner anteriorly. Fore wings broad, with very narrow costal fold in male, costa somewhat convex, termen slightly oblique, nearly straight; ground colour golden yellow, in some parts creamer near marking edges, darkening internally; markings darker than ground colour, partially browner, similarly arranged as in A. badiaurea; costal dots, anterior part of subterminal blotch and the blotch at base of dorsum suffused black brown and black; small groups of blackish scales on edges of some marking elements in various parts of wing; cilia golden yellow. Hind wings cream, in distal part tinged ochreous, strongly suffused brownish or almost entirely brownish; cilia brownish cream, with browner lines.

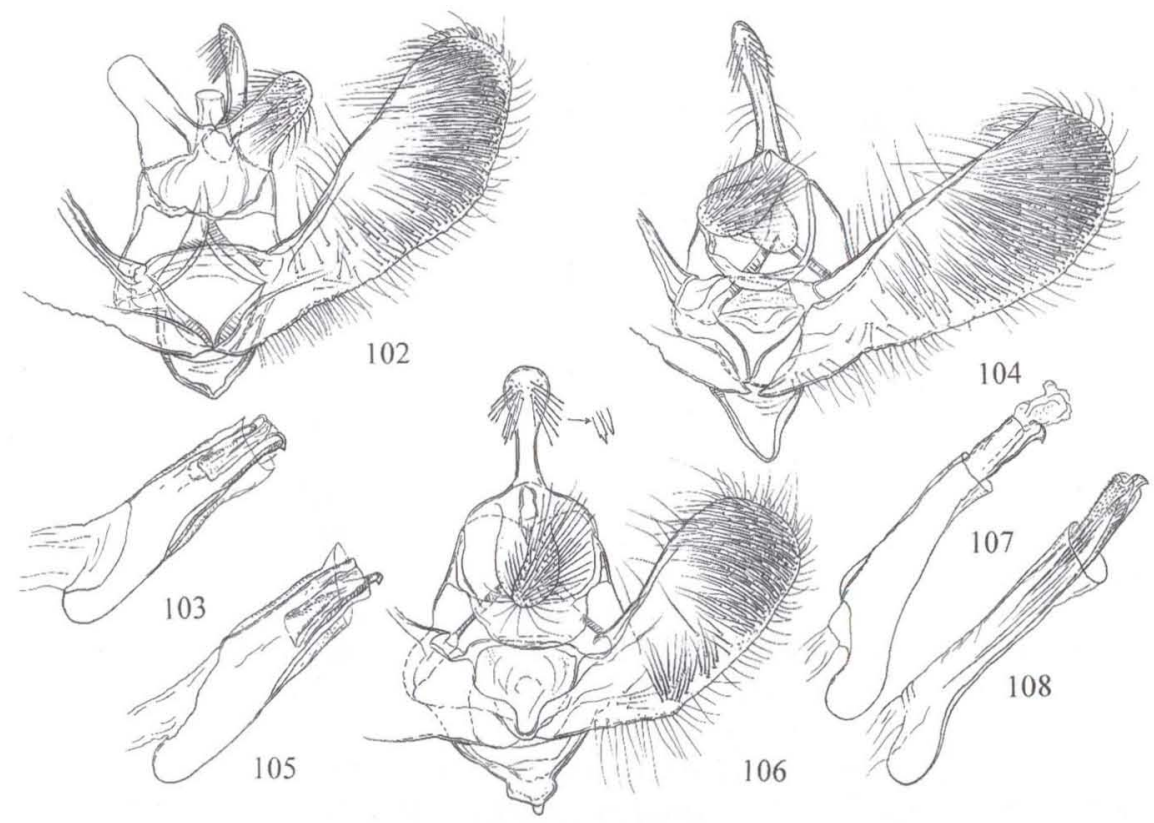

Figs 102-108. Genitalia of Heppnerographa and Monortha males. (102-103) H. lapilla sp.n., holotype, Brazil; (104-105) H. brasiliana sp.n., holotype, Brazil; (106-107) H. ecuatorica sp.n., holotype, Ecuador; (108) M. pleodontia Razowski, aedeagus, Costa Rica.

Markings variable in colour and intensity; majority of specimens with brownish black suffusion, often strong. In several individuals subterminal markings reach apex and extends to middle of wing; in some specimens there is an elongate mark before disc and a paler, parallel C-shaped mark more dorsally.

Male genitalia (Figs 88-91). Uncus shorter and broader than in A. badiaurea; socii slender, membranous in distal third, fused with hami; hami slender, curved beyond fused part. Valvae elongate-ovate; sacculus with distinct terminal thorn; transtilla strongly convex dorsally, emarginate dorso-laterally, with some minute apical processes. Aedeagus with ventro-posterior part ending in a minute thorn; coecum penis small. 

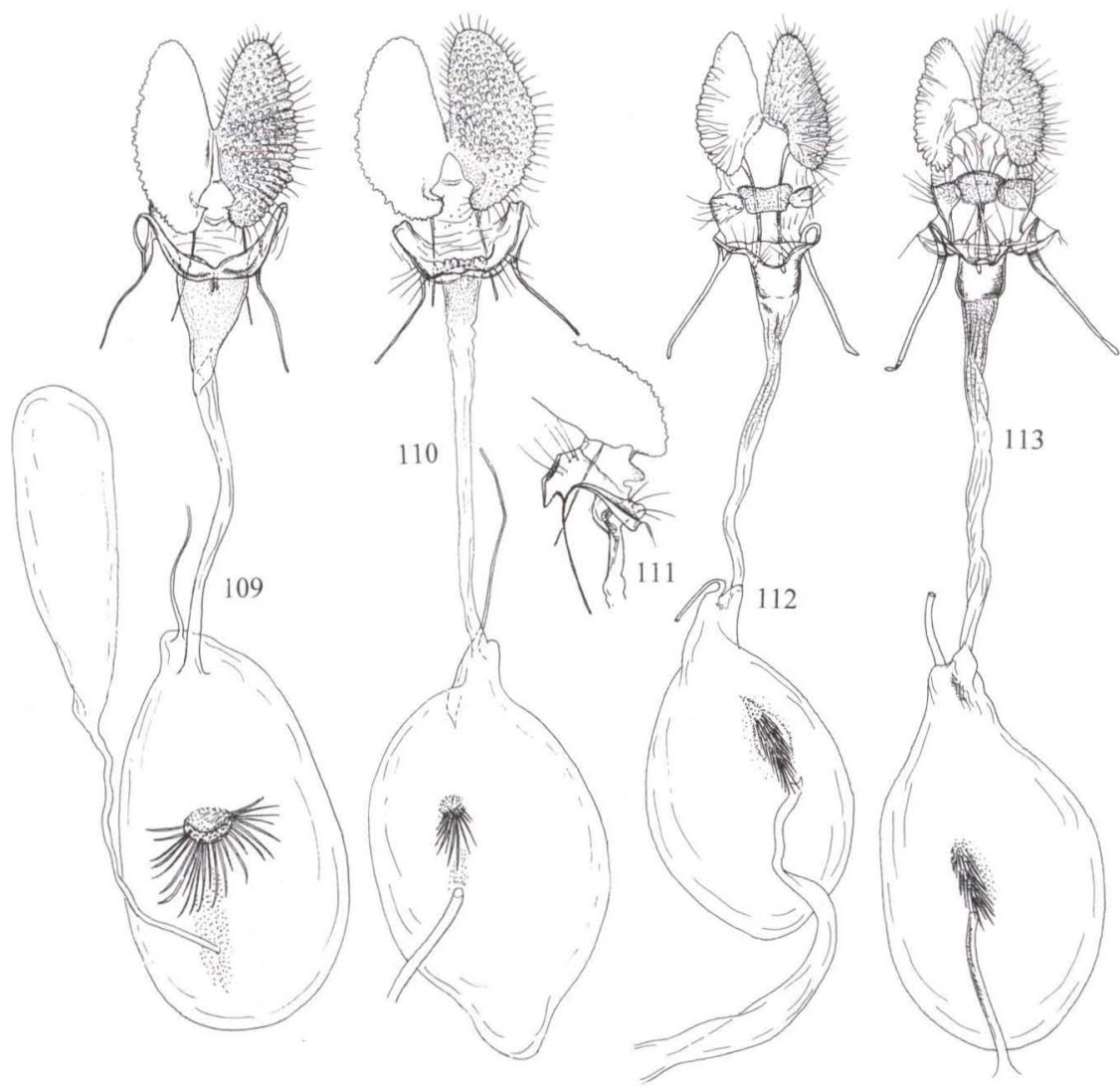

Figs 109-113. Genitalia of Auratonota females. (109) A. hydrogramma (Meyrick), Costa Rica; (110-111) A. petalocrossa petalocrossa (Meyrick), Costa Rica; (112) A. spinivalva cubana ssp.n., paratype, Cuba; (113) A. serotina sp.n., paratype, Mexico.

Female genitalia. Similar to those of $A$. badiaurea but with much smaller sterigma, lateral parts slender and anterior edge somewhat expanding medially; colliculum less concave ventrally before sterigma than in $A$. badiaurea; ductus bursae much shorter, sclerite at base of ductus seminalis smaller.

Holotype male. BRAzIL: Paraná, Quastro Barras, Banhado, 800 m, 6.VI.1970 (Becker) [3671]. Paratypes. 25 specimens: 1 female, same data as holotype (Becker) [3672]; 10 same locality, 17, 22.II., 11.IV.,1.VIII., 30.X., 27-28.XI.1970 (Becker \& Laroca) [14594, 14596, 14597, 34432, 34454, 34488, 34516, 34572]; 1 female, Paraná, Guaraqueçaba, 9.XII. 1970 (Becker) [55973]; 1, Paraná Morretes, Marumbi, 500 m, 17.XII.1969 (Laroca \& Becker); 2, Paraná, Curitiba, 920 m, 16.XII.1974, 4.II.1975 (Becker) [3669, 3670]; 3 females: São Paulo, SP, 1000 m, 29.I.1993 (Becker) [86825]; 1 female, CE[ará], Guaramiranga, 1000 m, 9.VI.1994 (Becker) [92155]; 2 females, R[io de] J[aneiro], Petrópolis 650m, 10-20.X.1995 (Becker) 
[86026], 2 females, R[io de] J[aneiro], Teresópolis, 1000 m, 15.I.1985 (Becker) [54998]; 1 female, S[anta] C[atarina], Brusque, 100 m, 15-20.I.1983 (Becker) [51872]; 1 female, BA[hia], Camacán, 400-700 m, 13-14.IV.1992 (Becker) [84778] (VOB, ISEZ).

Remarks. Externally rather similar to $A$. aurantica but with markings resembling more closely that in $A$. badiauera from which it differs strongly in colour.

\section{Auratonota omorpha sp.n.}

Figs 31,117

Wing span $18 \mathrm{~mm}$. Labial palpi ca 2, median joint subtriangular, cream, brownish ring in middle of second segment; remaining parts of head yellowish; thorax concolorous, with pale rusty marks. Fore wings as in previous species, with termen weakly oblique, almost straight; costal fold long, very narrow; ground colour whitish with large groups of refractive, pearl white scales along edges, suffused ochreous medially except for large subcostal blotch; markings rust brown with dark brown suffusions at dorsum postbasally, diffuse in median and subterminal areas, with diffuse edges; cilia dirty cream, with ferruginous divisions. Hind wings brown with a few ochreous cream dots in distal area; cilia paler.

Female genitalia (Fig. 117). Papillae anales broad, tapering posteriorly, with large antero-median lobe; apophyses thin; lateral lobes of sterigma broad, rounded, well sclerotized posteriorly; anterior part of sterigma broad, membranous, weakly separate from colliculum; the latter tapering terminally; ductus bursae scobinate beyond middle; ductus seminalis from base of ductus bursae, ventrally; signum anterior.

Holotype female. Costa RicA: Braulio Carrillo, 1100mm, VII.1981 (Becker) [44802].

Remarks. Distinguished from in the genus by dark rust coloration and small areas of ground colour.

\section{Auratonota magnifica sp.n.}

Figs 10, 92, 93

Wing span $33 \mathrm{~mm}$. Head cream ochreous; labial palpi ca 2, rust along middle, laterally; thorax similar to head, tegulae more grey. Fore wings not expanding terminally, costa weakly convex, apex broad, rounded, termen rather oblique, hardly convex; ground colour yellowish cream, yellow or ochreous yellow along edges; markings ferruginous; several transverse narrow fasciae in basal half, well marked at costa and dorsum, rather weak in median cell; large suffusion from before end of cell to apex, paler towards tornus, marked by two blotches of ground colour situated on median veins; white line limiting apical area followed by smaller mark at apex; two or three dots at termen near tornus; cilia yellowish ochreous, basal line rust. Hind wings yellowish cream tinged orange mainly along margins; cilia much creamer, concolorous at apical area.

Male genitalia (Figs 92, 93). Uncus strong, broad terminally, expanding dorso-terminally; hami broad; socii slender, reaching beyond middle of hami. 

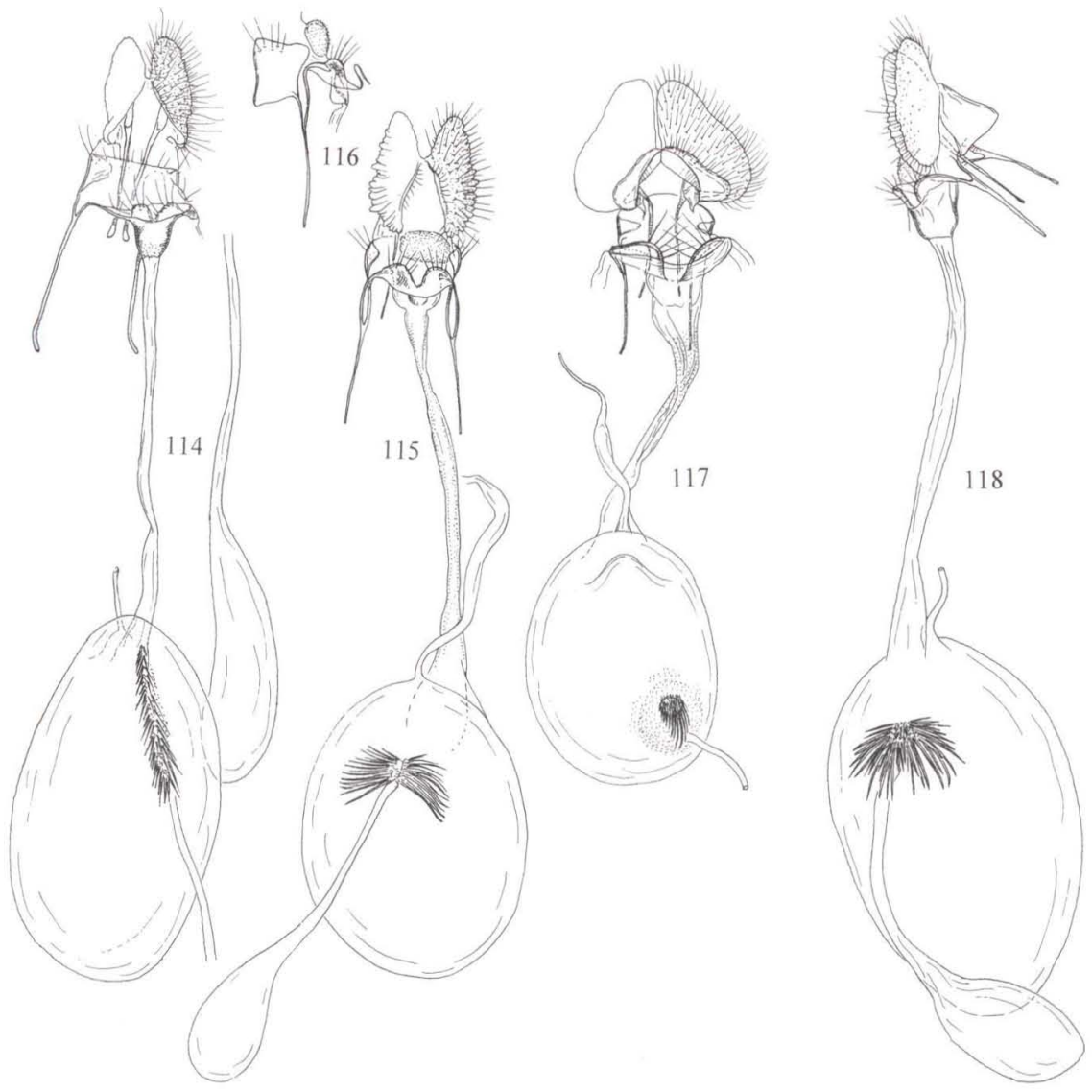

Figs 114-118. Genitalia of Auratonota and Heppnerographa females. (114) A. virgata sp.n., paratype, Ecuador; (115-116) A. badiaurea sp.n., paratype, Brazil; (117) A. omorpha sp.n., holotype, Costa Rica; (118) H. tricesimana (Zeller), Costa Rica.

Saccus long, slender. Valvae proportionally small, somewhat broadening in distal third; sacculus thick, ending in distinct, sharp process. Aedeagus slender, slightly longer than costa of valvae.

Holotype male. Venezuela: Ar.[agua], Rancho Grande $1100 \mathrm{~m}, 16 . \mathrm{VI}$. 1973 (J.C. \& K.G. Shaffer) at light in montane tropical forest (USNM). Paratypes: 8 males, same locality, 1-5.XI.1966 (S. \& D. Duckworth), 7-8.VI.67 (Duckworth), 22.VI-14.VII.1967 (Poole); Ar.[agua], Portachuelo Pass 1100 m, 22-3.VII, 1967 (Poole), G.S. 21899 (USNM, VOB).

Remarks. This robust species differs strongly from all known Chlidanotini, resembling a cossid species of the genus Cossula Bailey, 1882. Despite this no character distinguishing it from Auratonota was found. 


\section{Pseudocomotis J.W. Brown, 1989}

Pseudocomotis J.W. Brown, 1989a: 440, figs 1,2. Type species: Orthotaenia scardiana Dognin, 1905: 86 , by original designation.

Two autapomorphies. Excavation of caudal edge of the valvae and the presence of a patch of spines near mid-ventral part of valvae define the group (BROWN 1989a). The possession of the 'spines' of the venter of the uncus is, according to Brown, shared with Monortha. There was no opportunity to check these spines in the genus, however in all examined representatives of Chlidanotini these are, in fact, strong, modyfied, often apically bifurcate scales. Five species were originally included by BROWN (1989a), all distributed at high elevations along the Andes, as listed below.

\section{Pseudocomotis scardiana (Dognin, 1905)}

Orthotaenia (?) scardiana Dognin, 1905: 86. Holotype male, ECUADOR: El Monje pres Loja, 1894 (USNM) [examined].

Eulia scardiana; Meyrick, 1912b: 38; 1913: 38.

Orthocomotis scardiana; Clarke, 1955: 156; Razowski, 1982: 29.

Pseudocomotis scardiana; J.W. Brown, 1989a: 442, figs 3, 6.

BROWN (1989a: 443) extends its range to Peru.

\section{Pseudocomotis serendipita J.W. Brown, 1989}

Pseudocomotis serendipita J.W. Brown, 1989a: 444, figs 4, 7. Holotype male, EcuAdor: Morona-Santiago, Rio Culebrillas, 34 km SE Gualaceo, 2200 m, 22-23.X.1987 (Rawlins, Young $\&$ Davidson (CMNH) [not examined].

\section{Pseudocomotis albolineana J.W. Brown, 1989}

Pseudocomotis albolineana J.W. Brown, 1989a: 444, figs 5, 8. Holotype male, EcuAdoR: Carchí, $35 \mathrm{~km}$ W Tufino, west slope, cloud forest, 3120 m, $20 . X I .1987$ (Davidson \& Young) (CMNH) [not examined].

\section{Pseudocomotis citroleuca (Meyrick, 1912)}

Cnephasia citroleuca Meyrick, 1912b: 683. Holotype male, ColomBIA: San Antonio, 5800 ft, XI.1907 (BMNH) [not examined].

Orthocomotis citroleuca: Clarke, 1955: 155; 1958: 160.

Pseudocomotis citroleuca; J.W. Brown, 1989: 444.

\section{Pseudocomotis agatharcha (Meyrick, 1926)}

Eulia agatharcha Meyrick, 1926: 253; Clarke, 1958: 116, fig. 4. Holotype female, ColomBiA: C[entral] Cordilleras, $12500 \mathrm{ft}, \mathrm{XI} .1920$ (BMNH) [not examined].

Pseudocomotis agatharcha; Brown, 1989a: 445.

\section{Macrochlidia J.W. Brown, 1990}

Macrochlidia J.W. Brown, 1990b: 370. Type-species: Macrochlidia major J.W. Brown, 1990, by subsequent designation by BROWN (1991: 701).

Erected to include two species and regarded as closely related to Monortha. However, according to the characters it seems closer to Auratonota and Pseudocomotis, as already discussed in the introduction. The best character to differenciate this genus is the dull colloration of fore wings. 


\section{Macrochlidia major J.W. Brown, 1990}

Macrochlidia major J.W. Brown, 1990b: 373, figs 2, 4, 5. Holotype male, ColomBIA: Magdalena, Sierra de Santa Marta, 2800 m, 10 ${ }^{\circ} 54^{\prime} \mathrm{N}, 73^{\circ} 58^{\prime} \mathrm{W}$, Oxford Expedition to Colombia, 3.VII-2.IX.1973 $(\mathrm{BMNH})$ [not examined].

\section{Macrochlidia minor J.W. Brown, 1990}

Macrochlidia minor J.W. Brown, 1990b: 373, figs 3, 6. Holotype male, VenEzUELA: Aragua, Choroni Pass, 1400 m, 10.I.1966 (S. \& D. Duckworth) (USNM) [not examined].

\section{Utrivalva Razowski, 1987}

Utrivalva Razowski, 1987: 67. Type-species: Utrivalva usurpata Razowski, 1987, by original designation.

Described to include two species: U. usurpata Razowski, 1987 and $U$. melitocrossa (Meyrick, 1926), sharing two presumed autapomorphies: uncus ventro-posteriorly broadened, and presence of a basal lobe on the costal region of valvae. The base of socii are very close to the hami and the distal edge of the sterigma forms two median processes (in A. usurpata only).

\section{Utrivalva usurpata Razowski, 1987}

Utrivalva usurpata Razowski, 1987: 67, figs 7-10, 15-17. Holotype male, GUATEMALA: Volcan Sta. Maria (Schaus \& Barnes) (BMNH) [examined].

\section{Utrivalva melitocrossa (Meyrick, 1926)}

Eulia melitocrossa Meyrick, 1926: 235; Clarke, 1958: 132, figs 3-3b. Lectotype male, ColomBIA: San Antonio, W. Colombia, $5800 \mathrm{ft}$, XI.1907 (BMNH), designated by Clarke, 1958: 132 [examined]. Utrivalva melitrocrossa; Razowski, 1987: 68.

\section{Heppnerographa Razowski, 1987}

Heppnerographa Razowski, 1987: 63. Type-species: Heppnerographa arammclaina Razowski, 1987, by original designation.

Originally erected to include the type-species, six more are included here. Its presumed autapomorphy is the complete fusion of hami with the socii. In some species (e.g. H. tricesimana) the hami are visible in form of a rigid inner edge of the fused structure, in other ones (e. g. H. brasiliana) there is no trace of hami and only a drooping uniform lobe is present. Intermediate stages are represented by $H$. carchiana and $H$. lapilla.

\section{Heppnerographa tricesimana (Zeller, 1877) comb.n.}

Figs $29,94-97,118$

Conchylis [sic!] tricesimana Zeller, 1877: 128. Holotype female, [PANAMA]: Chiriqui (Ribbe) (NMHU) [not traced].

Material examined. Twenty four specimens, 2, CosTA RicA: Turrialba, 600 m, 8.VII, 15.VIII.1971 (Becker) [3990, 4008); 1 female, ECUADOR: Past.[atza], Mera, 1300 m, XII.1992 (Becker) [100677]; 2 males PuerTo Rico: Patillas, 590 m, VIII.1987 (Becker) [68255]; 20, BRAZIL, Paraná: Quatro Barras, Banhado, 800 m, 12.IV, 29.VIII, 27.XI.1970; 27.II, 26.III.1971 (Becker) [3673-3675, 34501, 34533, 34573, 34596] (VOB, ISEZ). 
BROWN (1993) mentions it as a widespread species, including Jamaica. In the USNM there are three more specimens from Volcan Santa Maria, Guatemala and Juan Viñas, Costa Rica.

This species is rather variable in size; examined specimens have $18-23 \mathrm{~mm}$ wing span. It also varies in coloration: there are paler and darker specimens, with distinct subterminal suffusion in fore wings, or with pale markings varying from pale ochreous to ferruginous; subterminal dots often whitish, distinctly dark edged.

The genitalia of those of our specimens are figured here (Figs 94-97, 118).

\section{Heppnerographa arammclaina Razowski, 1987}

Fig. 30

Heppnerographa arammclaina Razowski, 1987: 64, figs 3-5. Holotype male, CosTA RiCA: Tuis, 28.V-4.VI. (Schaus) (USNM) [examined].

Material examined. Six specimens, CosTA RicA: Turrialba, 600 m, VII.1981 (Becker) [46078] (VOB, ISEZ).

\section{Heppnerographa ardea sp.n.}

Figs $15,98,99$

Wing span $22 \mathrm{~mm}$. Head cream; labial palpi ca 3; thorax yellowish cream, tegulae mixed ochreous in basal half. Fore wings broad with termen weakly sinuate; ground colour pale golden yellow with distinct glossy dots forming series of blotches; markings golden brown, rather pale, edged pearl white; markings represented by three narrow lines extending from dorsum to $2 / 3$ of costa and apex, crossed by two fasciae running from costa; two incomplete lines in basal area; cilia concolorous with ground-colour. Hind wings creamy suffused ochreous along margins; cilia creamy.

Male genitalia (Figs 98, 99). Uncus large with strong latero-terminal parts; socii fused with hami forming a rigid hairy process; saccus rather small. Valvae expanding terminally, rounded in distal part; aedeagus as long as costa of valvae.

Holotype male. ECUADOR: Carchí, Maldonado, 2200 m, 9-11.I.1993 (Becker) [105233], G.S. 21904.

Remarks. Externally similar to $H$. tricesimana from which differs in golden hue of the ground colour forming larger blotches and to A. moronana which has broader subterminal markings. Easily distinguished by unique shape of uncus.

\section{Heppnerographa carchiana sp.n.}

Figs $13,100,101$

Wing span $13 \mathrm{~mm}$. Head whitish, vertex tinged pale ochreous; labial palpi ca 2, tinged brownish laterally; thorax brownish with basal half of tegulae brown. Fore wings rather uniformly broad throughout, apex sharp, termen oblique, slightly sinuate; ground colour whitish, partially suffused brownish, weakly tinged ferruginous in middle area; markings pale brown represented by incomplete fascia forming 
three smaller costal blotches and three larger dorsal elements; small blotch at tornus; diffuse suffusion marked with series of darker dots subterminally; cilia concolorous with ground colour, basal line brownish. Hind wings brownish cream, much browner along margins; cilia concolorous with wing, whitish in anal area.

Male genitalia (Figs 100, 101). Uncus long, broadening subterminally; remainder of hami forming a rigid inner edge, distal part broad, angulate, hairy. Saccus broad, short. Valvae ovate; sacculus to one third of ventral edge of valvae. Aedeagus somewhat shorter than valva.

Holotype male. ECUADOR: Carchí, Maldonado, 2200 m, 9-11.I.1993 (Becker) [105238], G.S. 21893.

\section{Heppnerographa lapilla sp.n.}

Figs $33,102,103$

Wing span $11 \mathrm{~mm}$. Head and thorax brownish grey; labial palpi ca 2, creamy. Fore wings slightly expanded distally, termen oblique, almost straight; ground-colour ochreous orange, suffused black from base to $2 / 3$, near cream, diffuse blotch; creamy dot at end of median cell; costal strigulae minute, whitish; cilia ferruginous yellow with blackish divisions beyond apex and mid termen. Hind wings brownish grey, cilia concolour.

Male genitalia (Figs 102, 103). Uncus slightly expanding subterminaly; hami in form of rather broad, well sclerotized inner part of socii; saccus broad. Valvae narrow in basal third. Aedeagus shorter than costa of valva.

Holotype male, BrAZIL: M[inas] G[erais], Caraça, 1300 m, 25.X.1994 (Becker \& Sattler) [93559], G.S. 21905.

Remarks. This species is characterized by reduced markings and strong median suffusion extending almost to base of wing. In dark specimen the brown suffusion is large, marked with whitish streak at end of median cell; in one specimen there is only an ochreous brownish costal triangle. It also varies in size (one specimen $15 \mathrm{~mm}$ wing span). These specimens (Paraná: Quatro Barras; Santa Catarina: Brusque; Rio de Janeiro: Itatiaia, are not included in the type-series (VOB, ISEZ).

\section{Heppnerographa brasiliana sp.n.}

Figs $34,104,105$

Wing span $13 \mathrm{~mm}$. Head and thorax pale ferruginous brown; labial palpi ca 2 , with second segment triangular, third short. Very similar to $H$. lapilla but fore wings more expanded terminally, termen less oblique, almost straight. Fore wings almost entirely yellowish ferruginous, darker near middle of costa, yellowish beyond this suffusion, diffuse fascia from costa to cubital veins; whitish streak et end of median cell; termen paler than ground colour, with several creamer dots; costal strigulae minute; numerous whitish blue dots scattered chiefly in basal half; cilia yellow tinged ochreous, with blackish divisions at apex and beyond mid-termen. Hind wings brown; cilia slightly paler. 
Male genitalia (Figs 104, 105). Similar to those of H. lapilla but uncus longer, socii drooping, slender basally, rounded, broad terminally; saccus slenderer and valvae slightly broader in basal portion.

Holotype male. BRAzIL: M[inas] G[erais], Caraça, 1300 m, 1-2.IV.1992 (Becker) [85256], G.S. 21919.

\section{Heppnerographa ecuatorica sp.n.}

Figs $35,106,107$

Wing span 12.5. Head, thorax and shape of fore wings as in H. lapilla. Fore wings ground colour yellowish brown, paler beyond end of median cell near whitish streak, brown suffusion rather triangular, suffused blackish towards costa, edged by rows of bluish white dots; numerous similar dots all over surface; cilia as in former species. Hind wings brownish cream, more fuscous outwards; cilia paler.

Male genitalia (Figs 106, 107). Similar those of $H$. brasiliana but uncus club-shaped, valvae shorter and aedeagus thiner, longer. Apical part of saccus with small process.

Holotype male. ECUADOR: Carchí, Maldonado, 2200 m, 9-11.I.1993 (Becker) [105229], G.S. 21920.

\section{Monortha Razowski \& Becker, 1981}

Monortha Razowski \& Becker, 1981: 396. Type-species: Monortha funesta Razowski \& Becker, 1981: 396 , by original designation.

Characterized by strong reduction of the hami developed as small median sclerites closely approached to one another (unified in pleodontia), and spinose socii. Males with outer split on valvae. Females habitus and forewing markings resembling those in Auratonota. The following four species included.

\section{Monortha corusca (Meyrick, 1912)}

Cnephasia corusca Meyrick, 1912: 11. Holotype male, FrenCH GUIANA: St. Jean de Maroni, I.1911 (BMNH) [not examined].

Eulia corusca: Clarke, 1958: 120, pl. 60, figs 4-4b.

Monortha corusca; Razowski, 1987: 65.

Characterized by thin, curved socii and small, medially broad uncus. This and $M$. funesta have ovate distal part of valvae and distinct spine-like process at end of sacculus.

\section{Monortha illaqueata (Meyrick, 1917)}

Capua illaqueata Meyrick, 1917: 6. Holotype female, FrENCH GuIANA: R.[iver] Maroni, 1916 (LeMoult) (BMNH) [not examined].

Capua illaquaeta Clarke, 1958: 71, pl. 35, figs 1-1c, misspelling.

Monortha illaqueata; J.W. Brown, 1989b: 321.

Known from single female redescribed by BRown (1989b: 321). Close to M. corusca. 


\section{Monortha funesta Razowski \& Becker, 1981}

Fig. 32

Monortha funesta Razowski \& Becker, 1981: 397. Holotype male, BRAZIL: Santa Catarina, Brusque, 28.XII.1969 (Becker) [11257] (VOB).

Closely related to $M$. corusca, differing in much broader socii and stout uncus. One additional specimen from BRAZIL: S[ão] P[aulo], Caraguatatuba, 1.V.1995 (Becker, 96424) (VOB).

\section{Monortha pleodontia Razowski, 1987}

Fig. 108

Monortha pleodontia Razowski, 1987: 65, fig 6. Holotype male: PANAMA: Rio Trinidad, III.1911 (Busck) (USNM).

Material examined. One male, CosTA RICA: Turrialba, 600 m, XI.1971 (Becker) [36019] (VOB).

Differs from the former two by having long socii, very small, fused hami, and process of sacculus absent. In the specimem from Costa Rica the aedagus (Fig. 108 , not figured in original description) is slender, as long as valva. The female from British Guiana (RAZOWSKI 1987, fig. 14), not included in the type-series, might represents a different species.

ACKNOWLEDGEMENTS. The authors are most gratefull to the authorities of The Natural History Museum, London, the National Museum of Natural History, Smithsonian Institution, Washington, DC and the American Museum of Natural History, New York, for permission to examine the collections under their care. It is also acknowledged an anonymous who made several corrections that improved the format of this work

\section{REFERENCES}

BRown, J.W. 1989a. Description of a new genus in the Chlidanotini and review of phylogenetic relationships among chlidanotine tribes (Lepidoptera: Tortricidae: Chlidanotinae). Ent. scand. 20 (4): 439-448.

- 1989b. Generic reassignments for Neotropical tortricid moths (Tortricidae). Jour. Lepid. Soc. 43 (4): 313-322.

. 1990a. New species and first U.S. record of Auratonota (Lepidoptera: Tortricidae). Fla Ent. 73 (1): 153-157.

. 1990b. Macrochlidia, new genus: The description of a remarkably large tortricid moth (Lepidoptera: Tortricidae: Chlidanotinae). Jour. N.Y. ent. Soc. 98: $369-375$.

-1991. Designation of a type species for Macrochlidia Brown (Lepidoptera (Tortricidae).). Jour. N.Y. ent. Soc. 99 (4): 701.

1993b. A new species of Auratonota (Lepidoptera: Tortricidae) from Dominica, West Indies. Pan-Pacif. Ent. 69 (4): 314-318.

Busck, A. 1920. Descriptions of new Central American Microlepidoptera. Insecutor Insit. Menstr. 8 (4-6): 83-95. 
Clarke, J.F.G. 1955. Neotropical moths in the genus Orthocomotis (Lepidoptera: Tortricidae). Trans. R. ent. Soc. Lond. 107: 139-168.

. 1958. Catalogue of the type specimens of Microlepidoptera in the British Museum (Natural History) described by Edward Meyrick. III. London, British Museum, 600p.

DognIN, P. 1905. Hétéroceres nouveaux de L'Amérique du Sud. Annls Soc. ent. Belg. 49: 61-90.

- 1912. Hétéroceres nouveaux de L’Amérique du Sud, 6. Rennes, Author, 51p.

HEPPNER, J.B. 1982. Synopsis of the Hilarographini (Lepidoptera: Tortricidae) of the World. Proc. ent. Soc. Wash. 84: 704-715.

HoRAK, M.; R.L. BROWN. 1991. Taxonomy and phylogeny, p.23-48. In: L.P.S. VAN DER GEEST \& H.H. EVENHUIS (Eds). Tortricoid pests, their biology, natural enemies and control. Amsterdam, Elsevier, XVIII+808p.

MEYRICK, E. 1912a. Exotic Microlepidoptera. Marlborough, Author, Vol. 1, $1-64 p$.

- 1912b. Descriptions of South American Microlepidoptera. Trans. ent. Soc. Lond. 1911: 673-718.

1917. Descriptions of South American Microlepidoptera. Trans. ent. Soc. Lond. 1917: 1-52. 320 . 352.

PoINAR, G.O. \& J.W. BRown. 1993. A new fossil tortricid (Lepidoptera: Tortricidae) from Dominican amber. Ent. scand. 24 (1): 25-29.

RAzowsKi, J. 1964. Meyrick types of Tortricoidea (Lepidoptera) in the Vienna Museum. Annls zool. Warsz. 22 (21): 451-481.

. 1982. Musculature of the male genitalia in Tortricinae (Lepidoptera, Tortricidae). Polskie Pismo ent. 51 (3-12): 3-12.

1987. Neotropical Chlidanotini (Lepidoptera: Tortricidae). Bull. Acad. Pol. Sci., sér. Sci. biol. 35: 61-71.

1990. Comments on the catalogue of Meyrick types of Tortricidae

(Lepidotera) in the Museum of Vienna with descriptions of new genera. Annls zool. Warsz. 43 (20): 395-405.

RAzOWSKI, J. 1982. Notes on Orthocomotis Dognin (Lepidoptera; Tortricidae) with descriptions of new taxa. Bull. Acad. Sci., Biol. Sci., Warsaw, 30: 29-36.

RAzOWSKI, J. \& V.O. BECKER. 1981. Brazilian Polyorthini (Lepidoptera, Tortricidae). Acta zool. cracov. 25 (16): 389-404.

TucK, K. 1981: A new genus of Chlidanotini (Lepidoptera, Tortricidae) from New Caledonia, with a key to genera and check-list of species. Syst. ent. 6: 337-346. ZELLER, P.C. 1877. Exotische Microlepidoptera. Horae Soc. ent. Ross. 13: 3-493. 